\title{
Effect of Push-Pull Ruthenium Complex Adsorption Conformation on the Performance of Dye Sensitized Solar Cells
}

\author{
Wilmmer A. A. Rosero, ${ }^{a, b}$ Robson R. Guimaraes, ${ }^{a}$ Tiago A. Matias ${ }^{\circledast a, c}$ and \\ Koiti Araki ${ }^{\odot *, a}$
}

a Departamento de Química Fundamental, Instituto de Química, Universidade de São Paulo, Av. Prof Lineu Prestes, 748, 05508-000 São Paulo-SP, Brazil

${ }^{b}$ Instituto de Pesquisas Energéticas e Nucleares (IPEN/CNEN-SP), Av. Professor Lineu Prestes, 2242, 05508-000 São Paulo-SP, Brazil

${ }^{c}$ Centro de Ciências Naturais e Humanas (CCNH), Universidade Federal do ABC (UFABC), Av. dos Estados, 5001, 09210-580 Santo André-SP, Brazil

\begin{abstract}
A new series of tris-(bipyridyl)ruthenium-like complexes based on the 4-tripheylamine2,2':6',2"-terpyridine (TPA) push-pull ligand was prepared by incorporation of 4-carboxypyridine (cpy), 4,4'-dicarboxi-2,2'-bipyridine (dcbpy) and 4-carboxyterpyridine ligands (ctpy) ligands, in order to adsorb them on $\mathrm{TiO}_{2}$ in different anchoring conformations. The electron photoinjection and electron recombination processes of the respective dye-sensitized solar cells were greatly influenced by the molecular structure, which defined the surface concentration and surface charge on $\mathrm{TiO}_{2}$, such that the photoconversion efficiency was 10 times larger for [Ru(py)(dcbpy) (TPAtpy)] than for the $[\mathrm{Ru}(\mathrm{cpy})(\mathrm{bpy})(\mathrm{TPAtpy})]\left(\mathrm{PF}_{6}\right)$ dye. Molecules anchoring in a more upright position and by a larger number of sites were shown to enhance the electron injection into $\mathrm{TiO}_{2}$ conduction band $(\mathrm{CB})$ improving the short-circuit current $\left(\mathrm{J}_{\mathrm{SC}}\right)$, open circuit voltage $\left(\mathrm{V}_{\mathrm{oc}}\right)$ and the overall photoconversion efficiency. However, a positive net charge in the dye increased the back electron-transfer reactions and induced a decrease in both $\mathrm{V}_{\mathrm{oc}}$ and conversion efficiency.
\end{abstract}

Keywords: ruthenium dye, push-pull dye, solar cells, photoelectrochemistry

\section{Introduction}

The development of our society is strongly dependent on energy, thus it is fundamental finding new and efficient alternatives such as based on solar energy. Dye sensitized solar cells, DSSC, are promising lightweight, low cost, flexible, and ease fabrication photoelectrochemical devices, ${ }^{1,2}$ in which the photosensitizer plays a key role in the conversion of light into electricity. Since O'Regan and Grätzel $^{3}$ first report on ruthenium polypyridyl complexes as the light harvesting units in DSSCs, a large variety of ruthenium complexes derivatives have been extensively studied in the search for efficient and durable solar cells. ${ }^{4-9}$

The photosensitizer is responsible for absorbing sun light promoting the subsequent charge separation/ injection into the semiconductor conduction band, the

*e-mail: koiaraki@iq.usp.br

Dedicated to Prof Henrique Eisi Toma on the occasion of his $70^{\text {th }}$ birthday. most fundamental step in the process, which depends on properties such as having $(i)$ an anchoring group for efficient electronic communication with the semiconductor, ${ }^{2}$ (ii) suitable highest occupied molecular orbital (HOMO) and lowest unoccupied molecular orbital (LUMO) potentials relative to $\mathrm{TiO}_{2}$ conduction band edge and electrolyte $\left(\mathrm{I}^{-} / \mathrm{I}_{3}^{-}\right)$ redox potential, ${ }^{3,10,11}$ and (iii) as broad absorption spectrum in the visible and near infrared region, with (iv) high molar absorptivities $(\varepsilon) .{ }^{12}$ However, the class of molecules that can fulfill all such requirements are scarce and new possibilities are been explored.

The push-pull systems, an electron donor (D) and an electron acceptor (A) connected by a $\pi$-systems, have achieved power conversion efficiencies as result of their improved light-harvesting abilities. The sensitizers are usually designed with extended $\pi$ conjugation frameworks and strengthened intramolecular charge transfer (ICT) by using suitable donors and acceptors. ${ }^{13-17}$ Concerning the donor, many sensitizers based on carbazole, indoline, 
phenothiazine, thiophene and perylene have been developed for fabricating DSSCs with high performance. ${ }^{13-17}$ For designing efficient sensitizers, it is crucial to select an excellent donor. In this context, triphenylamine moieties have been extensively applied because of their strong electron-donating character, which may be favorable for extending the absorption spectra by improving the ICT outcome. ${ }^{13-17}$ The donor-acceptor sensitizers with rod-like shape are been extensively explored but the elongated structure may facilitate the formation of aggregates ${ }^{18}$ and the recombination with the triiodide ion in the electrolyte solution. Therefore, complexes with starburst ligand conformation were designed by introducing triphenylamine as ligand, ${ }^{19}$ but the metal-to-ligand charge-transfer (MLCT) transition of such complexes generally involves only a moderate intensity band in the high energy region, that may not extend significantly into the visible region. This scenario is changed by the organic electron-donor unit in order to realize push-pull type ruthenium dye exhibiting additional strong intraligand charge-transfer (ILCT) bands in the visible region.

The design of new supramolecular systems relies on suitable choices of the subunits as well as their position, orientation and interactions to generate synergic effects enhancing the photoelectrochemical properties. For example, the introduction of an ancillary ligand with successive acid-base equilibria ${ }^{20}$ allowed the tuning of its electron donor-acceptor character, whereas ancillary electron donor groups interconnected by a bridging ligand of variable length decreased the recombination. ${ }^{21}$ On the other hand, the substitution of the ancillary ligands by strong $\pi$-electron donors tend to increase the $\mathrm{Ru}^{\mathrm{II}}$ complex HOMO level and can be used to tune the HOMO level position to devise more efficient ruthenium dye photosensitizers. ${ }^{22}$ Finally, ruthenium complexes bound at pyridylporphyrin mesopositions promoted a sevenfold enhancement of the energy efficiency by inhibiting aggregation, transferring energy to and accepting the hole generated in the porphyrin after electron injection, providing new insights for the design of more efficient supramolecular dyes..$^{23}$ Herein, we present the photophysical and electro-chemical properties of a new series of ruthenium complexes based on the 4-tripheylamine$2,2^{\prime}: 6^{\prime}, 2$ '"-terpyridine push-pull ligand with three different anchoring conformations through pyridine and polypyridine carboxylate derivatives. In fact, the electron photoinjection and electron recombination in the respective dye-sensitized solar cells were greatly influenced by the molecular structure, as well as by their charge and surface concentration (Scheme 1), such that the photoconversion efficiency was 10 times larger for $[\mathrm{Ru}(\mathrm{py})(\mathrm{dcbpy})(\mathrm{TPAtpy})]$ than for the [Ru(cpy)(bpy)(TPAtpy) $]^{+}$dye (py: pyridine, dcbpy: 4,4'-dicarboxi-2,2'-bipyridine, TPAtpy: 4-tripheylamine2,2',2"-terpyridine, cpy: 4-carboxypyridine and bpy: $2,2^{\prime}$-bipyridine).
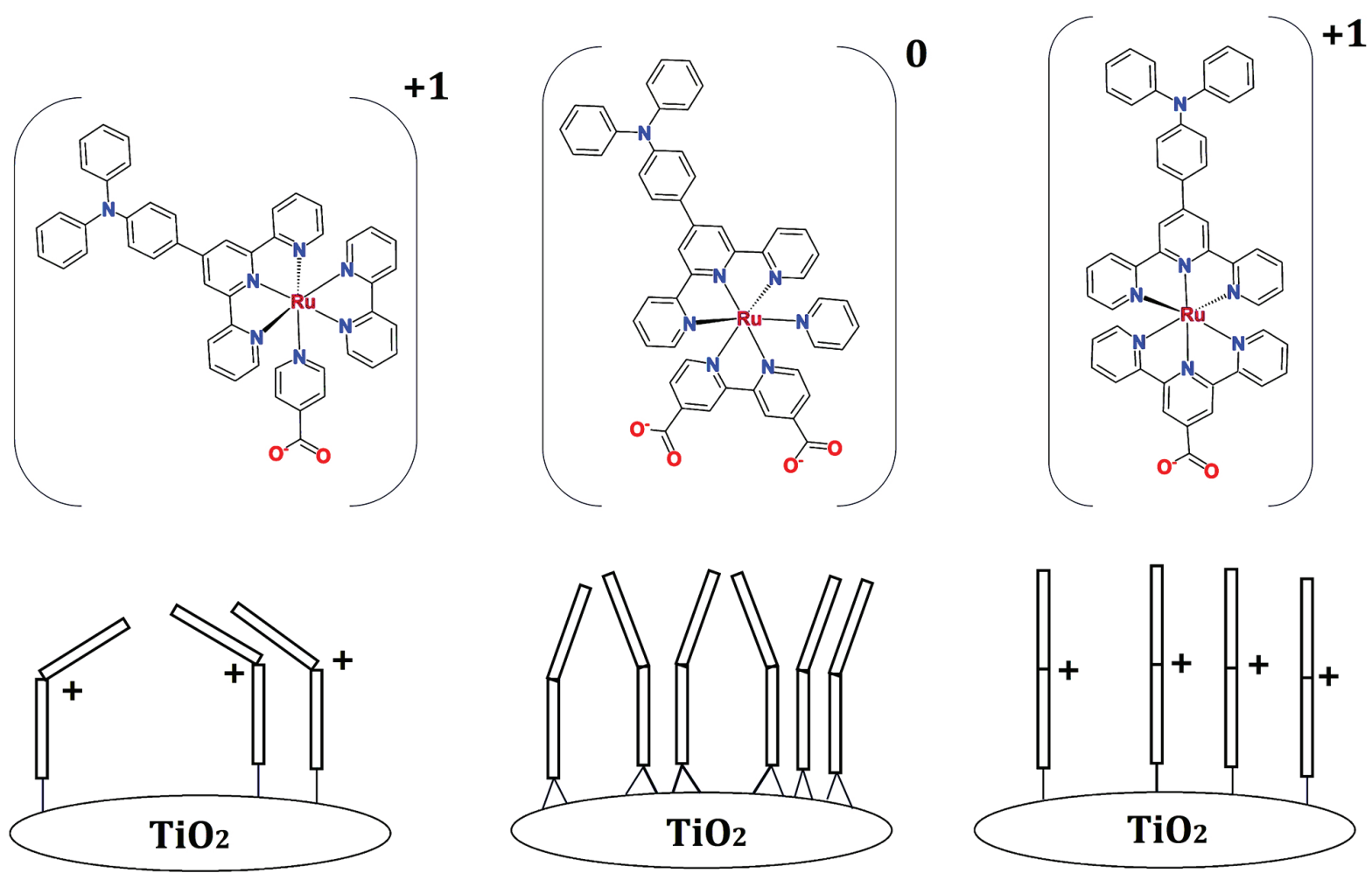

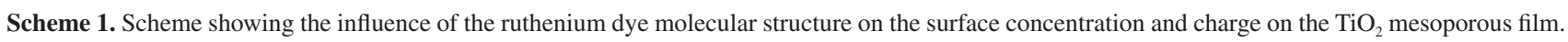




\section{Experimental}

\section{Materials and methods}

${ }^{1} \mathrm{H}$ and correlation spectroscopy (COSY) $2 \mathrm{D}{ }^{1} \mathrm{H}-{ }^{1} \mathrm{H}$ nuclear magnetic resonance (NMR) spectra were obtained on a Bruker DRX spectrometer of 300 and $500 \mathrm{MHz}$. The samples were prepared by dissolving $5 \mathrm{mg}$ per $500 \mu \mathrm{L}$ in the case of organic binders, and $3 \mathrm{mg}$ per $500 \mu \mathrm{L}$ of ruthenium complexes in pure deuterated solvents. The tetramethylsilane (TMS) was always used as an internal reference.

The mass spectra were obtained on an Esquire 3000 Plus Bruker Daltonics spectrometer, adjusting the capillary potential to $4000 \mathrm{~V}$ and the sample injection flow to $180 \mu \mathrm{L} \mathrm{h}^{-1}$.

Elemental analysis, which indicates the percentages of carbon, hydrogen, and nitrogen in the samples were measured on a PerkinElmer 2400 series II Analyzer equipped with a thermal conductivity detector (TCD).

Electron spectra of compounds in the UV-Vis region (190 to $1100 \mathrm{~nm}$ ) were obtained on a Hewlett Packard 8453A spectrophotometer, equipped with diode array detector, using quartz cells with an optical path of $1.00 \mathrm{~cm}$. The solutions were prepared in $N, N$-dimethylformamide (DMF).

Fluorescence spectra were obtained on a Quantamaster ${ }^{\mathrm{TM}}$ 50 NIP spectrofluorimeter using quartz cuvettes with the four polished faces and $1.00 \mathrm{~cm}$ optical path at room temperature. The solutions were prepared in DMF.

Cyclic and differential pulse voltammetric measurements were performed using an Autolab PGSTAT30 potentiostat/ galvanostat, and a conventional three-electrode cell, consisting of a platinum working electrode, a platinum wire auxiliary electrode and an $\mathrm{Ag} / \mathrm{AgNO}_{3}\left(0.01 \mathrm{~mol} \mathrm{~L}{ }^{-1}\right)$ $\mathrm{E}=+0.503 \mathrm{~V}$ vs normal hydrogen electrode (NHE) (organic medium). 0.1 M tetrabutylammonium perchlorate $\left(\mathrm{TBAClO}_{4}\right)$ was used as carrier electrolyte in DMF.

The spectroelectrochemical measurements were performed using a potentiostat/galvanostat EG \& G PAR model 173 in conjunction with an HP 8453A spectrophotometer. The measurements were made using a quartz cuvette with optical path restricted to $0.025 \mathrm{~cm}$, in which an electrochemical system was built consisting of a high transmittance gold network as a working electrode (minigrid), a platinum wire auxiliary electrode and a $\mathrm{Ag} / \mathrm{AgNO}_{3}$ reference electrode $(0.010 \mathrm{M})$, and $0.1 \mathrm{M}$ $\mathrm{TBAClO}_{4}$ as carrier electrolyte.

\section{Preparation of $\mathrm{TiO}_{2}$ nanoparticles and paste}

$12 \mathrm{~g}$ (0.2 mols) of acetic acid and $58.6 \mathrm{~g}$ (0.2 mols) of titanium isopropoxide were transferred into a round bottom flask, at room temperature. The reaction mixture was kept under stirring for $15 \mathrm{~min}$ and poured rapidly into $290 \mathrm{~mL}$ of water and kept under vigorous stirring $(700 \mathrm{rpm})$ for one hour. Then, $4 \mathrm{~mL}$ of concentrated nitric acid were added to the white precipitate, and the temperature maintained at $80^{\circ} \mathrm{C}$ for $40 \mathrm{~min}$. Water was added to complete a final volume of $370 \mathrm{~mL}$ and autoclaved at $250{ }^{\circ} \mathrm{C}$ for $12 \mathrm{~h}$. Then $2.4 \mathrm{~mL}$ of $65 \%$ nitric acid were added, and the dispersion processed for $75 \mathrm{~min}$ with a high-power titanium ultrasonic probe $(200 \mathrm{~W})$ at a frequency of 30 pulses every $2 \mathrm{~s}$. The resulting colloidal solution was concentrated to $13 \% \mathrm{TiO}_{2} \mathrm{~m} / \mathrm{m}$ in a rotary evaporator, centrifuged $(\times 3)$ and washed with ethanol $(\times 3)$ to remove the excess of nitric acid and other impurities, generating a white aqueous paste containing $40 \% \quad \mathrm{TiO}_{2}$ in mass. Then, an ethylcellulose solution in ethanol $(8 \mathrm{~g}$ of a $10 \% \mathrm{~m} / \mathrm{m}$ ) were transferred to a round bottom flask containing $16 \mathrm{~g}$ of $\mathrm{TiO}_{2}$ nanoparticles prepared according to the procedure described above, and $64.9 \mathrm{~g}$ of terpineol. The mixture was diluted to $280 \mathrm{~mL}$ with ethanol and carefully mixed alternating stirring with a hand mixer and an ultrasonic tip for three consecutive cycles. Then, ethanol and water were completely removed using a rotary evaporator.

\section{Preparation and sensitization of the mesoporous $\mathrm{TiO}_{2}$ films}

Mesoporous $\mathrm{TiO}_{2}$ films ( $20 \mu \mathrm{m}$ thick) were prepared by dispersing the $\mathrm{TiO}_{2}$ nanoparticles slurry on FTO (fluorinedoped $\mathrm{SnO}_{2}$ TEC $15,15 \Omega \mathrm{cm}^{-2}$ ) pieces, with $0.25 \mathrm{~cm}^{2}$ areas defined using Scotch tape, and spin-coating at $3000 \mathrm{rpm}$ for $10 \mathrm{~s}$. The $\mathrm{TiO}_{2}$ films were dried at room temperature, heated at $100{ }^{\circ} \mathrm{C}$ for $1 \mathrm{~h}$, sintered in a muffle furnace at $450{ }^{\circ} \mathrm{C}$ for $30 \mathrm{~min}$, transferred into a desiccator to cool and immersed in a $0.1 \mathrm{M}$ ruthenium dye solution for $12 \mathrm{~h}$. This same procedure was used to adsorb commercial N719 dye (Aldrich, Milwaukee, USA) from a 1:1 acetonitrile/ tert-butanol solution. Finally, the electrodes were washed with ethanol to remove the non-adsorbed dye and kept under vacuum overnight for complete removal of solvents and humidity.

\section{Preparation of the counter electrodes}

A $1 \mathrm{~mm}$ diameter hole was drilled with a diamond drill bit in each FTO piece to be used as counter electrode, washed with deionized-water and a $0.1 \mathrm{M} \mathrm{HCl}$ solution in ethanol, and cleaned with acetone in an ultrasonic bath for $10 \mathrm{~min}$. The organic material was then removed by heating to $400{ }^{\circ} \mathrm{C}$ for $15 \mathrm{~min}$, and cooled. As soon as the FTO plates reached room temperature, drops of a $0.005 \mathrm{~mol} \mathrm{~L}^{-1}$ of hexachloroplatinic acid solution in isopropanol were dripped homogeneously on the conductive glass surface. After evaporation of the solvent, 
the electrodes were calcined at $400{ }^{\circ} \mathrm{C}$ in air for $20 \mathrm{~min}$ to generate a thin platinum metal layer.

\section{Assembly and characterization of dye sensitized solar cells (DSSCs)}

The solar cells were assembled by intercalating a Surlyn frame in between the FTO/platinum counter electrode and the dye sensitized mesoporous $\mathrm{TiO}_{2}$ electrode, by carefully pressing them in an oven at $100{ }^{\circ} \mathrm{C}$ for $15 \mathrm{~min}$, in order to completely seal the cell and prevent short circuit. Soon after cooling, the electrolyte was injected through the hole in the counter electrode, which was immediately sealed with a Surlyn film and a glass plate, thus completing the assembly of the DSSCs. The electrolyte was prepared by dissolving $0.5 \mathrm{~mol} \mathrm{~L}^{-1}$ of tert-butylpyridine (Aldrich, Milwaukee, USA), $0.6 \mathrm{~mol} \mathrm{~L}^{-1}$ of tetrabutylammonium iodide (Aldrich, Milwaukee, USA), $0.1 \mathrm{~mol} \mathrm{~L}^{-1}$ of lithium iodide (Aldrich, Milwaukee, USA) and $0.1 \mathrm{~mol} \mathrm{~L}^{-1}$ of resublimed iodine (Synth, Milwaukee, USA) in methoxypropionitrile.

Each DSSC was carefully fixed on an optical bench to perform the measurements in quadruplicate. I-V curves and electrochemical impedance spectroscopy (EIS) measurements were performed using a PGSTAT30 potentiostat/galvanostat while the devices were irradiated with an Oriel (AM 1.5, IEC, JIS, ASTM) solar simulator with power set to $100 \mathrm{~mW} \mathrm{~cm}^{-2}$ (AM $1.5 \mathrm{G}$ ). The irradiation source was calibrated with a Si cell (VLSI standards, Oriel P/N 91150 V) immediately before the measurements to ensure their validity and reproducibility. The source produces a homogeneous collimated beam of photons in an area of $5 \times 5 \mathrm{~cm}^{2}$. The impedance spectra were recorded in the 0.01 to $100,000 \mathrm{~Hz}$ frequency range superimposing an alternating potential with amplitude of $20 \mathrm{mV}$ to the open circuit voltage of the respective DSSC. The IPCE spectra were measured using an Oriel 69070 Spectroluminator and a Wavetek Meterman 5XL multimeter.

\section{Synthesis and characterization}

\section{4-(Diphenylamino)benzaldehyde}

A two-necked flask containing $25 \mathrm{~mL}$ of DMF was dissolved $5 \mathrm{~g}$ (2.2 mmol) of TPA. The solution was cooled to $0{ }^{\circ} \mathrm{C}$ and $1.98 \mathrm{~mL}$ of $\mathrm{POCl}_{3}$ were added dropwise, at the end of addition the mixture was heated and maintained at $80{ }^{\circ} \mathrm{C}$ for three hours. After this time, the mixture was cooled to room temperature and added to ice and water. The generated phosphoric acid was neutralized by adding dropwise a solution of $5 \mathrm{M} \mathrm{NaOH}$. The solid formed was filtered through a sintered plate funnel and washed with water to give a yellow solid. The yield was $95 \%$.

\section{TPAtpy}

$272 \mathrm{mg}$ (1 mmol) of 4-(diphenylamino)benzaldehyde were dissolved in $30 \mathrm{~mL}$ of ethanol and then $224 \mu \mathrm{L}$ ( $2 \mathrm{mmol}$ ) of acetylpyridine, $168 \mathrm{mg}$ ( $3 \mathrm{mmol}$ ) of $\mathrm{KOH}$ and $10 \mathrm{~mL}$ of $\mathrm{NH}_{4} \mathrm{OH}$ were added. The reaction mixture was heated, maintained at reflux temperature for twelve hours, under vigorous stirring. The resulting brown solution was vacuum filtered and the solid washed with cooled ethanol at $0{ }^{\circ} \mathrm{C}$ until the precipitate turned white. Finally, the solid was dried in the desiccator under vacuum. The yield was 50\%. ${ }^{1} \mathrm{H} \mathrm{NMR}\left(300 \mathrm{MHz}, \mathrm{CDCl}_{3}\right) \delta 7.08(\mathrm{tt}, 2 \mathrm{H}, J 7.25 \mathrm{~Hz})$, 7.13-7.21 (m, 6H), 7.27-7.33 (m, 4H), 7.34-7.37 (m, 2H), $7.80(\mathrm{~d}, 2 \mathrm{H}, J 8.79 \mathrm{~Hz}), 7.87(\mathrm{td}, 2 \mathrm{H}, J 7.73 \mathrm{~Hz}), 8.67$ (dt, $2 \mathrm{H}, J 7.95 \mathrm{~Hz}), 8.70-8.74$ (m, 4H).

\section{4'-(Furan-2-yl)-2,2':6',2"-terpyridine}

$3.5 \mathrm{~mL}$ (42 mmol) of furfural were dissolved in $80 \mathrm{~mL}$ of ethanol and then were added $9.5 \mathrm{~mL}(84 \mathrm{mmol})$ of acetylpyridine, $5.2 \mathrm{~g}(92.6 \mathrm{mmol})$ of $\mathrm{KOH}$ and $30 \mathrm{~mL}$ of $\mathrm{NH}_{4} \mathrm{OH}$. The mixture was maintained at reflux temperature for nineteen hours under vigorous stirring. The resulting brown solution was vacuum filtered and the solid washed with cooled ethanol at $0{ }^{\circ} \mathrm{C}$, a white solid was obtained. Finally, the solid was dried in the desiccator under vacuum for $24 \mathrm{~h}$. The yield was $47 \% .{ }^{1} \mathrm{H}$ NMR $\left(300 \mathrm{MHz}, \mathrm{CDCl}_{3}\right)$ $\delta 6.57(\mathrm{dd}, 1 \mathrm{H}, J 3.39,1.74 \mathrm{~Hz}), 7.12(\mathrm{~d}, 1 \mathrm{H}, J 3.48 \mathrm{~Hz})$, 7.36 (ddd, $2 \mathrm{H}, J 7.51 \mathrm{~Hz}), 7.59$ (d, $1 \mathrm{H}, J 1.83 \mathrm{~Hz}), 7.88$ $(\mathrm{td}, 2 \mathrm{H}, J 7.78 \mathrm{~Hz}), 8.65(\mathrm{~d}, 2 \mathrm{H}, J 8.06 \mathrm{~Hz}), 8.72(\mathrm{~s}, 2 \mathrm{H})$, $8.74(\mathrm{dt}, 2 \mathrm{H}, J 4.81 \mathrm{~Hz})$.

\section{[2,2':6',2"-Terpyridine]-4'-carboxylic acid (ctpy)}

$0.5 \mathrm{~g}(1.67 \mathrm{mmol})$ of 4'-(furan-2-yl)-2,2':6',2'-terpyridine were dissolved in $50 \mathrm{~mL}$ of $\mathrm{NaOH}$ solution, $\mathrm{pH}=13$, and the mixture heated to reflux. Then, were added $1.06 \mathrm{~g}(6.7 \mathrm{mmol})$ of $\mathrm{KMnO}_{4}$ and refluxed for two and a half hours under vigorous stirring. After this time, $1.66 \mathrm{~g}$ of $\mathrm{Na}_{2} \mathrm{~S}_{2} \mathrm{O}_{3}$ were added, in order to reduce the remaining excess of $\mathrm{MnO}_{4}$. Finally, the solution was filtered and neutralized with $\mathrm{HCl}$ to $\mathrm{pH}=5.4$, the precipitate filtered, washed with water, and dried in the desiccator under vacuum for twenty-four hours. The yield was $63 \%$. ${ }^{1} \mathrm{H}$ NMR $\left(300 \mathrm{MHz}, \mathrm{D}_{2} \mathrm{O}\right) \delta$ 7.19-7.26 (m, 2H), 7.66 (td, 3H, J 7.37 Hz), 7.85 (dd, 2H, J $8.06 \mathrm{~Hz}$ ), 7.99 (s, $2 \mathrm{H}), 8.30$ (dt, 2H, J $4.94 \mathrm{~Hz})$.

\section{$\left[\mathrm{RuCl}_{3}\right.$ (ctpy)]}

$0.5 \mathrm{~g}(1.80 \mathrm{mmol})$ of ctpy and $406 \mathrm{mg}(1.80 \mathrm{mmol})$ of $\mathrm{RuCl}_{3} \cdot 2 \mathrm{H}_{2} \mathrm{O}$ were dissolved in $50 \mathrm{~mL}$ of ethanol. The mixture was maintained at reflux temperature for three hours under vigorous stirring. The resulting brown solution was filtered on a sintered glass funnel and the solid washed with cooled ethanol at $0{ }^{\circ} \mathrm{C}$ and water, and 
finally dried in the desiccator under vacuum for twentyfour hours. The yield was $77 \% .{ }^{1} \mathrm{H}$ NMR $\left(300 \mathrm{MHz}, \mathrm{D}_{2} \mathrm{O}\right)$ $\delta 7.41$ (ddd, 2H, J 7.62 Hz), $7.87(\mathrm{td}, 2 \mathrm{H}, J 7.76 \mathrm{~Hz}), 8.09$ (d, 2H, J $7.91 \mathrm{~Hz}), 8.22$ (s, 2H), 8.50 (d, 2H, J $4.98 \mathrm{~Hz})$.

\section{[RuCl${ }_{3}$ (TPAtpy)]}

In $50 \mathrm{~mL}$ of ethanol, $305 \mathrm{mg}(0.64 \mathrm{mmol})$ of TPAtpy and $160 \mathrm{mg}(0.70 \mathrm{mmol})$ of $\mathrm{RuCl}_{3} \cdot 2 \mathrm{H}_{2} \mathrm{O}$ were added, and the mixture was refluxed for $4 \mathrm{~h}$. The mixture was filtered after reaching room temperature to give a brown solid which was washed with ethanol and dried under vacuum and used in the next step without purification. The yield was $90 \%$. This compound was used without further purification.

\section{[RuCl(bpy)(TPAtpy)](PF $\left.{ }_{6}\right)$}

In $50 \mathrm{~mL}$ of a $3: 1 \mathrm{v} / \mathrm{v}$ ethanol:water mixture, $401 \mathrm{mg}$ $(0.59 \mathrm{mmol})$ of TPAtpyRuCl $\mathrm{R}_{3}, 94 \mathrm{mg}(0.6 \mathrm{mmol})$ of bpy, $129 \mathrm{mg}$ of $\mathrm{LiCl}$ and $1 \mathrm{~mL}$ of 4-ethylmorpholine were dissolved into, and the mixture refluxed for $4 \mathrm{~h}$. The mixture was concentrated on the rotary evaporator and the complex precipitated with aqueous solution $\mathrm{NH}_{4}\left(\mathrm{PF}_{6}\right)$, vacuum dried in a desiccator and purified by silica gel column chromatography using polarity gradient (acetone:MetOH:LiCl aqueous solution 15:5:1 as eluent). The product was obtained after removal of the solvent and drying in a desiccator under vacuum, in $58 \%$ yield. ${ }^{1} \mathrm{H}$ NMR $\left(500 \mathrm{MHz}\right.$, acetone- $\left.d_{6}\right) \delta 7.13(\mathrm{ddd}, 1 \mathrm{H}$, $J$ 7.40 Hz), 7.19-7.22 (m, 1H), 7.23 (d, 4 H, J 8.55 Hz), 7.39-7.42 (m, 2H), 7.43 (d, 1H, J $7.32 \mathrm{~Hz}), 7.45$ (d, $1 \mathrm{H}$, J 7.32 Hz), 7.67-7.69 (m, 1H), 7.81-7.83 (m, 1H), 7.84-7.86 (m, 2H), $8.00(\mathrm{td}, 2 \mathrm{H}, J 7.78 \mathrm{~Hz}), 8.06-8.10$ (m, $1 \mathrm{H}), 8.15$ $(\mathrm{d}, 2 \mathrm{H}, J 8.85 \mathrm{~Hz}), 8.40(\mathrm{td}, 1 \mathrm{H}, J 7.93 \mathrm{~Hz}), 8.62(\mathrm{dd}, 1 \mathrm{H}$, $J 7.63 \mathrm{~Hz}), 8.83$ (d, 2H, J7.93 Hz), 8.90 (d, 1H, J7.93 Hz), 9.04 (s, 2H), 10.38 (ddd, 1H, J 5.65 Hz).

\section{[RuCl(dcbpy)(TPAtpy)](PF $)$}

In $50 \mathrm{~mL}$ of a $3: 1 \mathrm{v} / \mathrm{v}$ ethanol:water mixture, $496 \mathrm{mg}$ (0.72 mmol) of TPAtpyRuCl${ }_{3}, 177 \mathrm{mg}(0.72 \mathrm{mmol})$ of dcbpy (2,2'-bipyridine-4,4'-dicarboxylic acid), $172 \mathrm{mg}$ of $\mathrm{LiCl}$ and $1 \mathrm{~mL}$ of 4-ethylmorpholine. The mixture was refluxed for $4 \mathrm{~h}$, concentrated in the rotary evaporator and the complex precipitated with aqueous $\mathrm{NH}_{4}\left(\mathrm{PF}_{6}\right)$ solution, vacuum dried in a desiccator and purified by silica gel column chromatography using polarity gradient (DMF:ACN:MetOH:LiCl aqueous solution 9:3:1:1 as eluent). The product was obtained after removal of the solvent and drying in a desiccator under vacuum. Yield 40\%; ${ }^{1} \mathrm{H}$ NMR (500 MHz, dimethyl sulfoxide (DMSO- $d_{6}$ )) $\delta 7.19(\mathrm{~m}, 8 \mathrm{H}), 7.20(\mathrm{~m}, 8 \mathrm{H}), 7.36(\mathrm{t}, 1 \mathrm{H}, J 6.75 \mathrm{~Hz}), 7.43$ $(\mathrm{m}, 5 \mathrm{H}), 7.64$ (d, 3H, J 4.58 Hz), $8.03(\mathrm{t}, 1 \mathrm{H}, J 7.32 \mathrm{~Hz})$, $8.21(\mathrm{~d}, 2 \mathrm{H}, J 8.70 \mathrm{~Hz}), 8.44(\mathrm{~d}, 1 \mathrm{H}, J 5.95 \mathrm{~Hz}), 8.90(\mathrm{~d}$,
2H, J $8.47 \mathrm{~Hz}), 8.99$ (s, 1H), $9.14(\mathrm{~s}, 2 \mathrm{H}), 9.28$ (s, 1H), 10.26 (d, $1 \mathrm{H}, J 5.72 \mathrm{~Hz})$.

\section{[Ru(cpy)(bpy)(TPAtpy)](PF $)_{2}$}

$50 \mathrm{mg}(0.0547 \mathrm{mmol})$ of [RuCl(bpy)(TPAtpy)]( $\left.\mathrm{PF}_{6}\right)$ and $47 \mathrm{mg}(0.249 \mathrm{mmol})$ of $\mathrm{AgNO}_{3}$ were dissolved in $30 \mathrm{~mL}$ of an acetone:water (3:5) v/v mixture, refluxed for $4 \mathrm{~h}$, and filtered on a celite column to remove the precipitated silver chloride. The complex was removed from celite with $20 \mathrm{~mL}$ of acetone, the resulting solution and evaporated until complete removal of the solvent on a rotary evaporator. Then, $20 \mathrm{~mL}$ of an EtOH:water (1:1) $\mathrm{v} / \mathrm{v}$ mixture and $500 \mathrm{mg}$ of isonicotinic acid (cpy) were added into, the mixture refluxed for $24 \mathrm{~h}$, filtered on a celite column to remove excess ligand, the solution concentrated using a rotary evaporator under vacuum, and the product precipitated out with an aqueous $\mathrm{NH}_{4}\left(\mathrm{PF}_{6}\right)$ solution. The solid was washed with water to remove eventually remaining isonicotinic acid and dried under vacuum in a desiccator. Yield 94\%; ${ }^{1} \mathrm{H}$ NMR $\left(500 \mathrm{MHz}, \mathrm{DMSO}-d_{6}\right)$ $\delta 7.18(\mathrm{~d}, 6 \mathrm{H}, J 7.63 \mathrm{~Hz}), 7.19-7.22(\mathrm{~m}, 2 \mathrm{H}), 7.35(\mathrm{t}, 2 \mathrm{H}$, J 7.02 Hz), 7.40-7.45 (m, 5H), 7.45-7.48 (m, $1 \mathrm{H}), 7.52$ (t, $2 \mathrm{H}, J 6.56 \mathrm{~Hz}), 7.81$ (d, 2H, J 5.49 Hz), 7.87 (s, $1 \mathrm{H}), 7.89$ (d, 1H, J $6.41 \mathrm{~Hz}), 8.16(\mathrm{t}, 2 \mathrm{H}, J 7.93 \mathrm{~Hz}), 8.19$ (d, 2H, $J 8.85 \mathrm{~Hz}), 8.24$ (d, 1H, J 5.49 Hz), 8.68 (d, 1H, J $5.80 \mathrm{~Hz}$ ), 8.79 (br s, 1H), 8.99 (d, 2H, J 8.24 Hz), 9.07 (br s, 1H), $9.18(\mathrm{~s}, 2 \mathrm{H}) ; \mathrm{C}_{49} \mathrm{H}_{37} \mathrm{~F}_{12} \mathrm{~N}_{7} \mathrm{O}_{2} \mathrm{P}_{2} \mathrm{Ru} \cdot \mathrm{H}_{2} \mathrm{O}$ (1165.1) calcd. C 51.32, H 3.25, N 8.55; found C 50.22, H 3.56, N 8.22; $\mathrm{m} / \mathrm{z}$, calcd. for $\mathrm{C}_{49} \mathrm{H}_{37} \mathrm{~F}_{6} \mathrm{~N}_{7} \mathrm{O}_{2} \mathrm{PRu}[\mathrm{M}]^{+}:$1002.17, found: 1002.15 ; $\left[\mathrm{Ru}(\mathrm{Hcpy})(\right.$ bpy $)($ TPAtpy) $]\left(\mathrm{PF}_{6}\right)^{+}$.

\section{[Ru(py)(dcbpy)(TPAtpy) $]\left(\mathrm{PF}_{6}\right)_{2}$}

$50 \mathrm{mg}(0.0547 \mathrm{mmol})$ of [ $\mathrm{RuCl}(\mathrm{dcbpy})$ (TPAtpy)] $\left(\mathrm{PF}_{6}\right)$ and $43 \mathrm{mg}(0.249 \mathrm{mmol})$ of $\mathrm{AgNO}_{3}$ were refluxed for $4 \mathrm{~h}$ in $30 \mathrm{~mL}$ of an acetone:water (3:5) v/v mixture, and filtered on a celite column to remove the precipitated silver chloride. The ruthenium complex was removed from the celite bed with $20 \mathrm{~mL}$ of acetone, and the resulting solution evaporated until complete removal of the solvent on a rotary evaporator. Then, $20 \mathrm{~mL}$ of an EtOH:water $(1: 1) \mathrm{v} / \mathrm{v}$ mixture and $1 \mathrm{~mL}$ of pyridine was added into and this reaction mixture refluxed for $24 \mathrm{~h}$, concentrated in the rotary evaporator under vacuum, and the product precipitated with aqueous $\mathrm{NH}_{4}\left(\mathrm{PF}_{6}\right)$ solution. The solid was washed with water and dried under vacuum in a desiccator. Yield 98\%; ${ }^{1} \mathrm{H}$ NMR (500 MHz, DMSO- $\left.d_{6}\right) \delta$ 7.16-7.20 (m, 9H), 7.35 (t, 2H, J 7.02 Hz), 7.40-7.48 (m, 5H), 7.52 (t, 2H, J 6.56 Hz), 7.81 (d, 2H, J 5.49 Hz), 7.87 (br s, 1H), 7.89 (d, 2H, J 6.41 Hz), 8.16 (t, 2H, J7.93 Hz), 8.19 (d, 2H, $J 8.85 \mathrm{~Hz}), 8.24$ (d, 1H, J 5.49 Hz), 8.68 (d, 1H, J 5.80 Hz), 8.79 (br s, 1H), 8.99 (d, 2H, J 8.24 Hz), 9.07 (br s, 1H), 9.18 
(s, $2 \mathrm{H}) ; \mathrm{C}_{50} \mathrm{H}_{37} \mathrm{~F}_{12} \mathrm{~N}_{7} \mathrm{O}_{4} \mathrm{P}_{2} \mathrm{Ru} \cdot \mathrm{H}_{2} \mathrm{O} \cdot \mathrm{CH}_{3} \mathrm{CH}_{2} \mathrm{OH}$ (1255.2): calcd. C 49.77, H 3.61, N 7.81; found C 49.42, H 3.51, N 7.76; $\mathrm{m} / z$, calcd. for $\mathrm{C}_{50} \mathrm{H}_{37} \mathrm{~N}_{7} \mathrm{O}_{4} \mathrm{Ru}[\mathrm{M}]^{2+}: 450.60$, found: $450.59\left[\mathrm{Ru}(\mathrm{py})\left(\mathrm{H}_{2} \mathrm{dcbpy}\right)(\text { TPAtpy })\right]^{2+}$.

[Ru(TPAtpy)(ctpy)](PF $)_{2}$

$175 \mathrm{mg}(0.361 \mathrm{mmol})$ of $\left[\mathrm{RuCl}_{3}\right.$ (ctpy)], $172 \mathrm{mg}$ $(0.361 \mathrm{mmol})$ of TPAtpy ligand and $N$-ethylmorfoline $(0.5 \mathrm{~mL})$ were added into $30 \mathrm{~mL}$ of a $\mathrm{MeOH}: \mathrm{H}_{2} \mathrm{O}$ (5:1) mixture, refluxed for $12 \mathrm{~h}$ and evaporated until complete removal of the solvent on a rotary evaporator. The solid was purified by silica gel column chromatography using an acetone:MetOH:NaNO ${ }_{3(\text { sat) }}(3: 1: 1 \mathrm{v} / \mathrm{v})$ mixture. Yield 50\%; ${ }^{1} \mathrm{H} \mathrm{NMR}\left(500 \mathrm{MHz}, \mathrm{CDCN}_{3}\right) \delta 7.17$ (ddd, $\left.2 \mathrm{H}, J 7.31 \mathrm{~Hz}\right)$, 7.20 (ddd, $2 \mathrm{H}, J 7.31 \mathrm{~Hz}), 7.25$ (tt, $2 \mathrm{H}, J 7.39 \mathrm{~Hz}$ ), 7.27 $(\mathrm{dd}, 4 \mathrm{H}, J 8.58 \mathrm{~Hz}), 7.30(\mathrm{~d}, 2 \mathrm{H}, J 8.58 \mathrm{~Hz}), 7.41(\mathrm{~d}, 2 \mathrm{H}$, $J 4.77 \mathrm{~Hz}), 7.46$ (m, 6H), 7.95 (tt, $4 \mathrm{H}, J 7.67 \mathrm{~Hz}), 8.13$ $(\mathrm{d}, 2 \mathrm{H}, J 8.58 \mathrm{~Hz}), 8.65(\mathrm{~d}, 2 \mathrm{H}, J 8.27 \mathrm{~Hz}), 8.69(\mathrm{~d}, 2 \mathrm{H}$, $J 7.95 \mathrm{~Hz}), 8.99(\mathrm{~s}, 2 \mathrm{H}), 9.35(\mathrm{~s}, 2 \mathrm{H}) ; \mathrm{C}_{49} \mathrm{H}_{3} 5 \mathrm{~F}_{12} \mathrm{~N}_{7} \mathrm{O}_{2} \mathrm{P}_{2} \mathrm{Ru}$. $\mathrm{CH}_{3} \mathrm{CH}_{2} \mathrm{OH}$ (1191.2) calcd. C 51.43, H 3.47, N 8.23; found C 52.43, H 3.50, N 9.54; $m / z$, calcd. for $\mathrm{C}_{49} \mathrm{H}_{34} \mathrm{~N}_{7} \mathrm{O}_{2} \mathrm{Ru}[\mathrm{M}]^{+}$: 854.18, found: 853.8 [Ru(TPAtpy)(ctpy) $]^{+}$.

\section{Results and Discussion}

Preparation of the ligands and ruthenium dyes

The 4-terpyridine carboxylic acid (Hctpy) and 4-tripheylamine-2,2',2"-terpyridine (TPAtpy) ligands were prepared according with the Kröhnker ${ }^{24}$ method, by reaction of furfural or 4-(diphenylamino)benzaldehyde with 2-acetilpyridine and ammonium hydroxide solution in ethanol. ${ }^{25-27}$ These tridentate ligands were treated with
$\mathrm{RuCl}_{3} \cdot \mathrm{H}_{2} \mathrm{O}$ to obtain the respective trichloro complexes, $\left[\mathrm{RuCl}_{3}\right.$ (TPAtpy)] and $\left[\mathrm{RuCl}_{3}(\mathrm{Hctpy})\right]$, as intermediates. These neutral trichloro ruthenium(III) complexes are poorly soluble, and precipitated out in the reaction mixture. They were filtered, washed with ethanol, dried and used for the preparation of the desired ruthenium dye precursors as described below. The $\left[\mathrm{RuCl}_{3}\right.$ (TPAtpy)] was treated with 2,2'-bipyridine (bpy) or 2,2'-bipyridine-4,4'-dicarboxylic acid $\left(\mathrm{H}_{2} \mathrm{dcbpy}\right)$, in the presence of an excess of $\mathrm{LiCl}$ and the reducing agent 4-ethylmorpholine, to obtain the respective $[\mathrm{RuCl}(\text { bpy })(\mathrm{TPAtpy})]^{+}$and $\left[\mathrm{RuCl}\left(\mathrm{H}_{2} \mathrm{dcbpy}\right)(\mathrm{TPAtpy})\right]^{+}$ chloro complexes, (see Scheme 2). In these cases also, it is better first reducing the trichloro complex with zinc amalgam before the reaction with the bidentated ligands to avoid the formation of unwanted byproducts. ${ }^{28}$ Finally, these monochloro complexes were dissolved in a EtOH: $\mathrm{H}_{2} \mathrm{O}$ mixture ( $\mathrm{pH}$ 7) and reacted with $\mathrm{AgNO}_{3}$ generating the respective aqua complexes, that were treated, respectively, with an excess of pyridine (py) or conjugate base of the isonicotinic acid (cpy) to generate the $[\mathrm{Ru}(\mathrm{cpy})(\mathrm{bpy})$ (TPAtpy) $]^{+}$and $[\mathrm{Ru}(\mathrm{py})(\mathrm{dcbpy})$ (TPAtpy)] complexes. The $[\mathrm{Ru}(\mathrm{TPAtpy})(\mathrm{ctpy})]^{+}$complex was prepared by refluxing $\left[\mathrm{RuCl}_{3}(\mathrm{Hctpy})\right]$ and TPAtpy in a $\mathrm{MeOH}: \mathrm{H}_{2} \mathrm{O}(5: 1)$ mixture for $12 \mathrm{~h}$. In all cases, the solvent was partially removed in a rotary evaporator and the chloride counter ion exchanged with $\mathrm{PF}_{6}{ }^{-}$in order to make them soluble in organic solvents, thus allowing their purification by silica gel column chromatography using polarity gradient. These ruthenium dyes were designed to study the effect of the anchoring conformation on the mesoporous $\mathrm{TiO}_{2}$ surface, as well as of the TPA electron donor group, on the photoconversion efficiency of the respective dye sensitized solar cells.

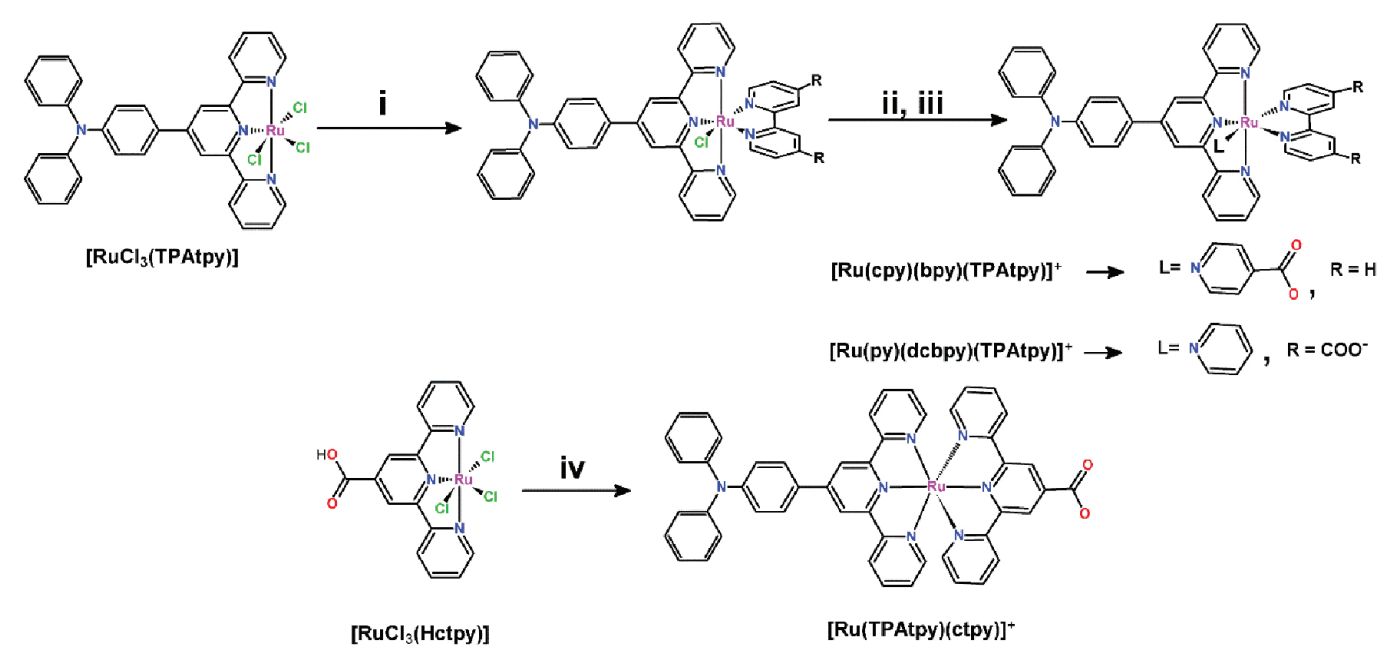

Scheme 2. Scheme depicting the strategy used to prepare the $[\mathrm{Ru}(\mathrm{TPAtpy})(\mathrm{ctpy})]\left(\mathrm{PF}_{6}\right),[\mathrm{Ru}(\mathrm{py})(\mathrm{dcbpy})(\mathrm{TPAtpy})]$ and $[\mathrm{Ru}(\mathrm{cpy})(\mathrm{bpy})(\mathrm{TPAtpy})]\left(\mathrm{PF}_{6}\right)$ push-pull ruthenium dyes. (i) $\mathrm{LiCl}$, bpy (or dcbpy) in 3:1 v/v ethanol:water mixture, refluxed for 4 h, followed by addition of $\mathrm{NH}_{4} \mathrm{PF}_{6(\mathrm{aq})}$. (ii) $\mathrm{AgNO}_{3}$ in acetone:water (3:5) v/v mixture, refluxed for $4 \mathrm{~h}$. Filtered on a celite bed and removed on a rotary evaporator. (iii) Pyridine (or isonicotinic acid) in EtOH:water (1:1) v/v mixture, refluxed for $24 \mathrm{~h}, \mathrm{NH}_{4} \mathrm{PF}_{6(\text { aq) }}$. (iv) TPAtpy ligand, $\mathrm{MeOH}: \mathrm{H}_{2} \mathrm{O}(5: 1)$ mixture, refluxed for $12 \mathrm{~h}, \mathrm{NH}_{4} \mathrm{PF}_{6(\mathrm{aq})}$. 


\section{Spectroscopic and electrochemical behavior of compounds}

The TPAtpy ligand has been characterized to understand the spectroscopic and electrochemical behavior of derived ruthenium dyes. The electronic spectrum of TPAtpy ligand in DMF (Figure 1a) shows two bands at 290 and $359 \mathrm{~nm}$ respectively ascribed to a $\pi_{(\text {tpy })}-\pi^{*}{ }_{(\text {tpy })}$ and n- $\pi^{*}{ }_{\text {(tpy) }}$ tpy intra-ligand (IL) transition ${ }^{29,30}$ and a $\pi_{\text {(TPA) }}-\pi^{*}{ }_{\text {(tpy) }}$ and $\mathrm{n}-\pi^{*}{ }_{\text {(TPA) }}$ intra-ligand charge-transfer (ILCT) transition. ${ }^{29,31}$ The electrochemical behavior of this ligand in DMF solution is shown in Figure $1 \mathrm{~b}$. The wave at $\mathrm{E}_{1 / 2}=1.21 \mathrm{~V}$ was associated to the monoelectronic oxidation of the triphenylamine group of TPAtpy, ${ }^{31}$ while the wave at $\mathrm{E}_{1 / 2}=-1.80 \mathrm{~V}$, in the limit of DMF solvent electrochemical window, was attributed to tpy reduction, all redox potentials of TPAtpy ligand and complexes are shown in Table 1. The spectroelectrochemical changes associated with the oxidation and reduction of TPAtpy ligand are shown in Figures 1a and 1c. The oxidation of TPAtpy ligand causes the disappearance of the ILCT band at $359 \mathrm{~nm}$, as expected for a process centered in the triphenylamine group generating the TPA*t tpy radical cation, thus affecting mainly the ILCT and $n-\pi *$ transitions. In fact, the new band around $320 \mathrm{~nm}$ was assigned to this radical cation. In the reduction side (Figure 1c), it is possible to see the decrease of the $\pi \rightarrow \pi^{*}$ and $n \rightarrow \pi^{*}$ bands, in addition to the appearance of intense absorption bands around 550 and $700 \mathrm{~nm}$, typical of the terpyridine radical anion TPAtpy ${ }^{-},{ }^{32}$ thus confirming our previous assignments.

The coordination of TPAtpy to $[\mathrm{Ru}($ Hctpy $)]$ produced the deep orange-red colored [Ru(TPAtpy)(ctpy)] $\left(\mathrm{PF}_{6}\right)$ complex displaying a spectral pattern in the UV region similar to that presented by the TPAtpy ligand itself with bands at 276 and $314 \mathrm{~nm}$ (Figure 2a, green line), respectively assigned to $\pi_{\text {(tpy) }} \rightarrow \pi^{*}$ (tpy) intra-ligand transition $^{29,30}$ and $\pi_{(\mathrm{TPA})} \rightarrow \pi^{*}{ }_{\text {(tpy) }}$ ILCT with contribution of transitions $\pi_{\text {(ctpy) }} \rightarrow \pi^{*}$ (ctpy) terpyridine ligand IL transition, that increase the relative intensity of the second band. In addition, the broad band at $499 \mathrm{~nm}$ was attributed to

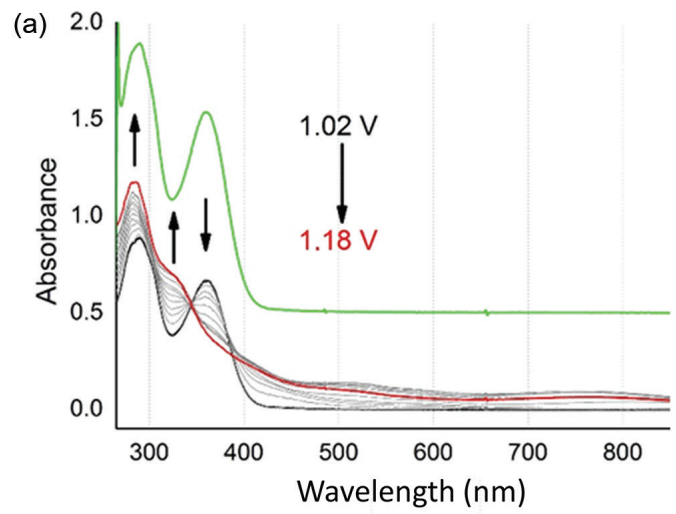

(b)
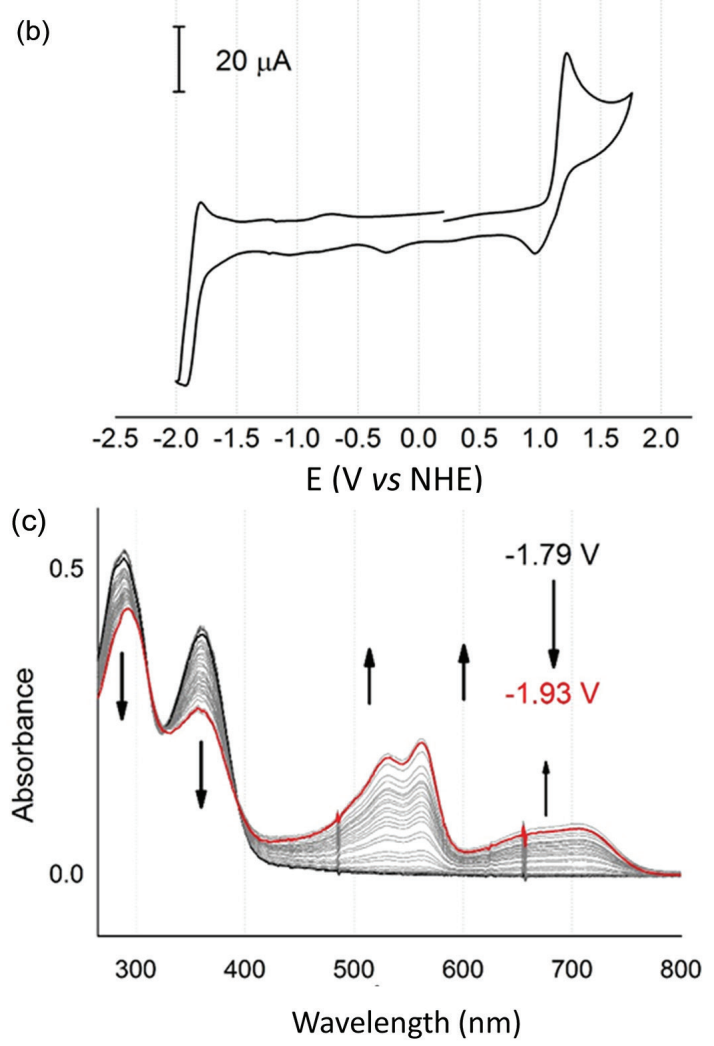

Figure 1. (a) The electronic spectrum of TPAtpy ligand (green line) and spectroelectrochemical changes associated with its oxidation, (b) cyclic voltammogram of a $1.0 \mathrm{mM}$ TPAtpy DMF solution and $0.10 \mathrm{M} \mathrm{TBAClO}_{4}$ as electrolyte, $v=100 \mathrm{mV} \mathrm{s}^{-1}$; and (c) spectroelectrochemical changes associated with reduction processes in DMF solution.

Table 1. Redox potentials (V vs NHE) of the push-pull ruthenium dyes in $0.10 \mathrm{M} \mathrm{TBAClO}_{4}$ DMF solution as electrolyte, $v=100 \mathrm{mV} \mathrm{s}^{-1}$

\begin{tabular}{|c|c|c|c|c|c|c|}
\hline \multirow{2}{*}{ Compound } & \multicolumn{6}{|c|}{ Redox potential / V } \\
\hline & TPAtpy $^{0 /+}$ & $\mathrm{Ru}^{\mathrm{IIIIII}}$ & $\mathrm{L}^{0 /-}$ & $\mathrm{L}^{-12-}$ & TPAtpy $^{0 /-}$ & $\mathrm{E}\left(\mathrm{S}^{+} / \mathrm{S}^{*}\right)$ \\
\hline TPAtpy & 1.21 & - & - & - & -1.80 & - \\
\hline$[\mathrm{Ru}(\mathrm{TPAtpy})(\mathrm{ctpy})]\left(\mathrm{PF}_{6}\right)$ & 1.17 & 1.45 & $-1.12^{\mathrm{a}}$ & $-1.39^{\mathrm{a}}$ & -1.85 & -0.64 \\
\hline$[\mathrm{Ru}(\mathrm{cpy})(\mathrm{bpy})(\mathrm{TPAtpy})]\left(\mathrm{PF}_{6}\right)$ & 1.16 & 1.38 & $-1.08^{\mathrm{b}}$ & $-1.32^{\mathrm{b}}$ & -1.60 & -0.67 \\
\hline$[\mathrm{Ru}(\mathrm{py})(\mathrm{dcbpy})(\mathrm{TPAtpy})]$ & 1.18 & 1.43 & $-1.10^{\mathrm{c}}$ & $-1.35^{\mathrm{c}}$ & -1.73 & -0.62 \\
\hline
\end{tabular}

${ }^{a}$ ctpy ligand redox potential; ${ }^{b} b p y$ ligand redox potential; ${ }^{c} d c b p y$ redox potential. L: bpy or dcbpy ligands; $\mathrm{E}\left(\mathrm{S}^{+} / \mathrm{S}^{*}\right)$ : redox potential of excited state of dyes; TPAtpy: 4-tripheylamine-2,2',2"-terpyridine; ctpy: 4-carboxy-2,2',2"-terpyridine; py: pyridine, dcbpy: 4,4'-dicarboxi-2,2'-bipyridine, cpy: 4-carboxypyridine; bpy: 2,2'-bipyridine. 

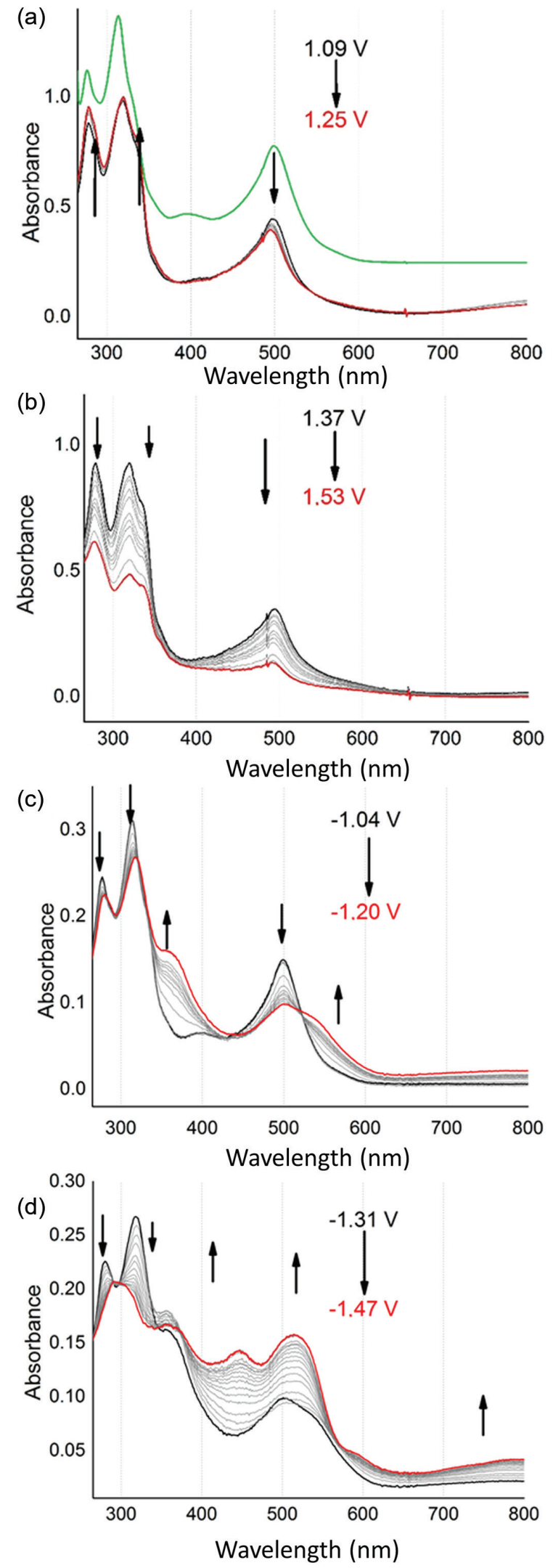

Figure 2. (a) Electronic spectrum of $[\mathrm{Ru}(\mathrm{TPAtpy})(\mathrm{ctpy})]\left(\mathrm{PF}_{6}\right)$ (green line), and spectroelectrochemical changes associated with the first oxidation (a), second oxidation (b), first reduction (c) and second reduction (d), both in DMF solution.

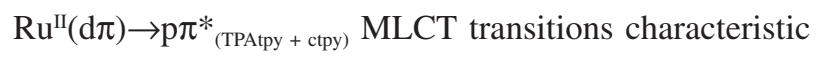
of ruthenium(II) bis-terpyridine complexes. ${ }^{33}$

Ruthenium polypyridyl complexes generally exhibit rich electrochemistry owing to several accessible redox states associated with the metal center and the polypyridyl ligands. ${ }^{34}$ Typical cyclic voltammograms and square wave voltammetry of the $[\mathrm{Ru}$ (TPAtpy)(ctpy) $]\left(\mathrm{PF}_{6}\right)_{2}$ complex in DMF are shown in Figure 3a. The first wave on positive region at $\mathrm{E}_{1 / 2}=1.17 \mathrm{~V}$ has very similar profile to the one associated with the oxidation of free TPAtpy ligand.

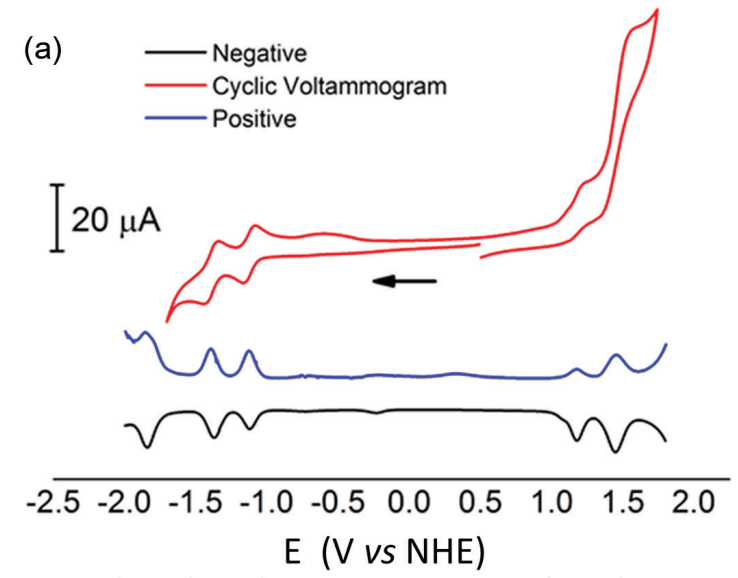

(b)
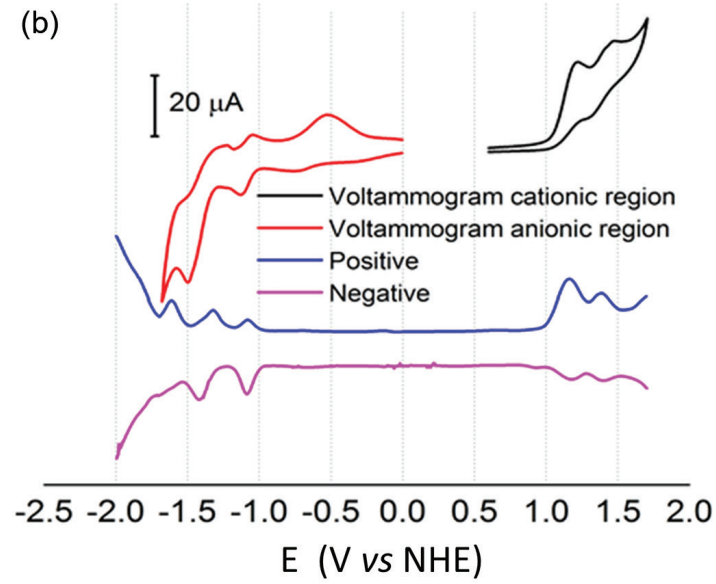

Figure 3. Cyclic voltammogram of (a) $1.0 \mathrm{mM}$ [Ru(TPAtpy)(ctpy)]( $\left.\mathrm{PF}_{6}\right)$ and (b) $1.0 \mathrm{mM}\left[\mathrm{Ru}(\right.$ cpy)(bpy)(TPAtpy) $]\left(\mathrm{PF}_{6}\right)$, in $0.10 \mathrm{M} \mathrm{TBAClO}_{4} \mathrm{DMF}$ solution as electrolyte, $v=100 \mathrm{mV} \mathrm{s}^{-1}$.

The coordination of TPAtpy onto [Ru(ctpy)] moiety increased the TPAtpy oxidation potential about $80 \mathrm{mV}$. As the potential was made more positive, the MLCT band of the $[\mathrm{Ru}(\mathrm{TPAtpy})(\mathrm{ctpy})]\left(\mathrm{PF}_{6}\right)$ complex decreased slightly while the largest change occurred in the $\pi \rightarrow \pi^{*}$ and $n \rightarrow \pi^{*}$ bands (Figure 2a). This behavior is similar to that observed in the monoelectronic oxidation of the triphenylamine moiety of the complex to the radical cation. The other wave at $\mathrm{E}_{1 / 2}=1.45 \mathrm{~V}$ (Figure 3a) was assigned to the $\mathrm{Ru}^{\mathrm{III/I}}$ redox couple as confirmed by the spectroelectrochemical changes shown in Figure 2b, particularly the disappearance 
of the MLCT band at $499 \mathrm{~nm}$. The waves at $\mathrm{E}_{1 / 2}=-1.12 \mathrm{~V}$ and $\mathrm{E}_{1 / 2}=-1.39 \mathrm{~V}$ were associated to the first and second reduction of the ctpy ligand, respectively. In Figure $2 \mathrm{c}$ it is possible to notice the changes caused by the application of $-1.12 \mathrm{~V}$ to the complex, especially the decrease and displacement of the MLCT, $\pi \rightarrow \pi^{*}$ and $\mathrm{n} \rightarrow \pi^{*}$ bands, characteristic of the formation of the ctpy- species. $^{35}$ In the second reduction process (Figure 2d), the ctpy band at $314 \mathrm{~nm}$ was extinguished concomitantly with the appearance of bands at 450, 575 and $700-900 \mathrm{~nm}$ as expected upon reduction of the ctpy ${ }^{-}$species to the ctpy $^{2-}$ dianion, increasing the absorption in the visible and nearinfrared regions..$^{27,36}$ Finally, the last wave at $\mathrm{E}_{1 / 2}=-1.85 \mathrm{~V}$ was associated to the reduction of the TPAtpy ligand, that was only observed by square wave voltammetry due to the exponential increase of current associated to the solvent reduction process in the cyclic voltammograms.

The coordination of bpy (or dcbpy) and cpy (or pyridine) to $[\mathrm{Ru}(\mathrm{TPAtpy})]$ moiety produced the $[\mathrm{Ru}(\mathrm{cpy})$ (bpy)(TPAtpy) $]\left(\mathrm{PF}_{6}\right)$ and [Ru(py)(dcbpy)(TPAtpy)] complexes, both displaying a deep red color in solution. The electronic spectrum of the [Ru(cpy)(bpy)(TPAtpy)] $\left(\mathrm{PF}_{6}\right)$ complex in DMF is shown in Figure 4a (green line), where bands at 291 and $318 \mathrm{~nm}$ corresponding to the $\pi \rightarrow \pi^{*}$ IL transitions of TPAtpy and bpy ligands and $\mathrm{n}-\pi^{*}$ transitions of the TPAtpy ligand can be observed. Moreover, the bands at 410 and $508 \mathrm{~nm}$ were assigned to a $\mathrm{Ru}^{\mathrm{II}}(\mathrm{d} \pi) \rightarrow \mathrm{p} \pi^{*}{ }_{\text {(TPAtpy+bpy) }}$ MLCT transition characteristic of the $[R u(b p y)(t p y)]$ moiety. ${ }^{29,33}$ The $[R u(p y)(d c b p y)$ (TPAtpy)] complex displayed a very similar spectrum to the analogous $\left[\mathrm{Ru}(\mathrm{cpy})(\mathrm{bpy})(\mathrm{TPAtpy})^{+}\right.$species (see Figure 5a, green line) as can be noted by comparing the peak wavelengths of all three complexes listed in Table S1 (Supplementary Information section).

The cyclic voltammograms of [Ru(cpy)(bpy)(TPAtpy)] $\left(\mathrm{PF}_{6}\right)$ showed five redox waves (see Figure $3 \mathrm{~b}$ ). The wave at $\mathrm{E}_{1 / 2}=1.16 \mathrm{~V}$ is very similar to that associated to the oxidation of TPAtpy ligand to the radical cation, inducing a small decrease of the MLCT band but an increase of the absorption of the IL $\pi \rightarrow \pi^{*}$ (bpy + cpy) $_{\text {band }}$ at $291 \mathrm{~nm}$ (Figure 4a). The wave at $\mathrm{E}_{1 / 2}=1.38 \mathrm{~V}$ was attributed to the $\mathrm{Ru}^{\mathrm{IIIII}}$ redox couple, as confirmed by the spectroelectrochemical changes shown in Figure 4b, particularly the disappearance of the MLCT bands at 410 and $508 \mathrm{~nm} .{ }^{29}$ Three redox processes at $\mathrm{E}_{1 / 2}=-1.08$, -1.32 , and $-1.60 \mathrm{~V}$ were found in the negative region. The first and second one was assigned to the $\mathrm{bpy}^{\mathrm{ol}}$ and bpy $^{-12-}$ couples. The first reduction process is characteristic of bpy- formation, ${ }^{29}$ leading to a decrease in the bpy IL $\mathrm{p} \pi \rightarrow \mathrm{p} \pi^{*}$ transitions at 291 and $318 \mathrm{~nm}$ concomitantly with the MLCT band at $508 \mathrm{~nm}$, followed by the increase
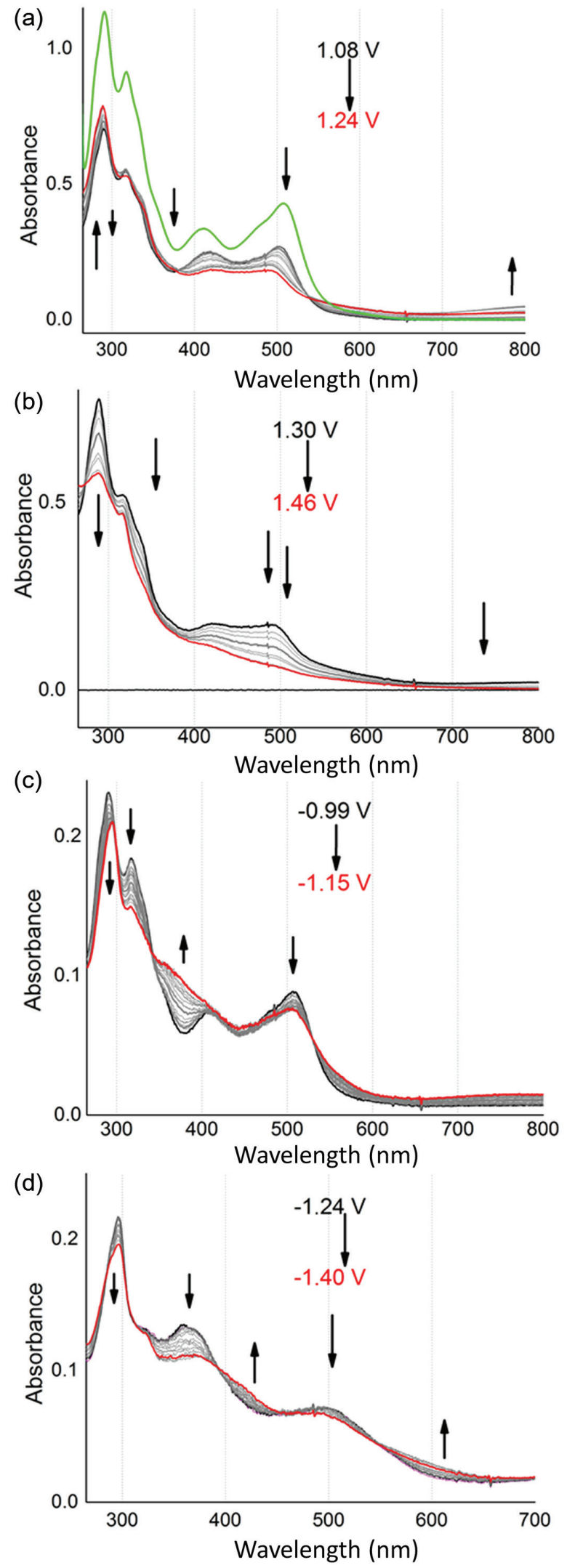

Figure 4. Electronic spectra (green line) and spectroelectrochemical changes associated with the (a) first oxidation and (b) second oxidation, and to the (c) first and (d) second reduction of the [Ru(cpy)(bpy)(TPAtpy)] $\left(\mathrm{PF}_{6}\right)$ complex in DMF solution. 
of absorption in the 350-400 $\mathrm{nm}$ range (Figures $4 \mathrm{c}$ and $4 \mathrm{~d}$ ). The generation of bpy ${ }^{2-}$ species resulted in a decrease of the 300 and $350 \mathrm{~nm}$ bands while the band around $400 \mathrm{~nm}$ increased, as observed in analogous ruthenium complexes..$^{29}$ Finally the process at $\mathrm{E}_{1 / 2}=-1.60 \mathrm{~V}$ was associated with TPAtpy reduction since the electrochemical behavior of $[R u(p y)(d c b p y)(T P A t p y)]$ was very similar to that of $[\mathrm{Ru}(\mathrm{cpy})(\mathrm{bpy})(\mathrm{TPAtpy})]\left(\mathrm{PF}_{6}\right)$, where the redox potentials were more or less shifted due the more acceptor character of the dcbpy ligand (Figure 5a). The redox potentials of all complexes are summarized in Table 1, and the spectroelectrochemical behavior of the $[\mathrm{Ru}(\mathrm{py})(\mathrm{dcbpy})$ (TPAtpy) $]\left(\mathrm{PF}_{6}\right)$ complex are shown in Figures $5 \mathrm{~b}$ and $5 \mathrm{c}$. In short, both $[\mathrm{Ru}(\mathrm{cpy})(\mathrm{bpy})(\mathrm{TPAtpy})]\left(\mathrm{PF}_{6}\right)$ and $[\mathrm{Ru}(\mathrm{py})$ (dcbpy)(TPAtpy)] presented very similar spectroscopic and electrochemical behavior despite the significant differences expected in the binding conformation on mesoporous $\mathrm{TiO}_{2}$ surface.

\section{Push-pull ruthenium dyes as photosensitizers}

From the spectroscopic and electrochemical data, were estimated the relative energies of the frontier orbitals for the complexes (Figure 6a). ${ }^{21}$ In this diagram, the excited state potential of all dyes are around $-0.14 \mathrm{~V}$ more negative than the $\mathrm{TiO}_{2}$ conduction band edge $(-0.50 \mathrm{~V})$, ensuring a electron injection into the conduction band (ii) after electronic excitation ( $i$ ) of ruthenium(II) polypyridyl moiety (Figure 6b). Furthermore, the ruthenium(III) polypyridyl portion generated after photoinjection process, has a redox potential $0.2 \mathrm{~V}$ more positive than TPA fragment of terpyridine ligand enabling the electron transfer (iii). As consequence, the hole can be transported far from $\mathrm{TiO}_{2}$ surface contributing to increased device performance. ${ }^{21}$ Also, the TPAtpy redox potential is more positive than the energy level of $\mathrm{I}^{-} / \mathrm{I}_{3}{ }^{-}$redox couple, indicative of enough driving force for regenerating the oxidized TPA tpy by electrolytes. Lastly, the reaction between the ruthenium(III) polypyridyl moiety and $\mathrm{I}^{-} / \mathrm{I}_{3}{ }^{-}$ electrolyte was not excluded.

DSSCs were assembled using the [Ru(TPAtpy) (ctpy) $]\left(\mathrm{PF}_{6}\right),[\mathrm{Ru}(\mathrm{cpy})(\mathrm{bpy})(\mathrm{TPAtpy})]\left(\mathrm{PF}_{6}\right)$ and $[\mathrm{Ru}(\mathrm{py})$ (dcbpy)(TPAtpy)] push-pull dyes as photosensitizers, and characterized by current density-potential (JV) and incident light to current (IPCE) curves and electrochemical impedance spectroscopy (EIS).

The JV curves (Figure 7a) were used to obtain the shortcircuit current $\left(\mathrm{J}_{\mathrm{SC}}\right)$, open circuit voltage $\left(\mathrm{V}_{\mathrm{OC}}\right)$ and overall efficiency of the solar cells. The efficiency parameter was calculated by equation 1 where $\mathrm{P}_{\max }$ is the maximum power of the solar cell per unit area and $\mathrm{P}_{\text {lamp }}$ is the power of the (a)

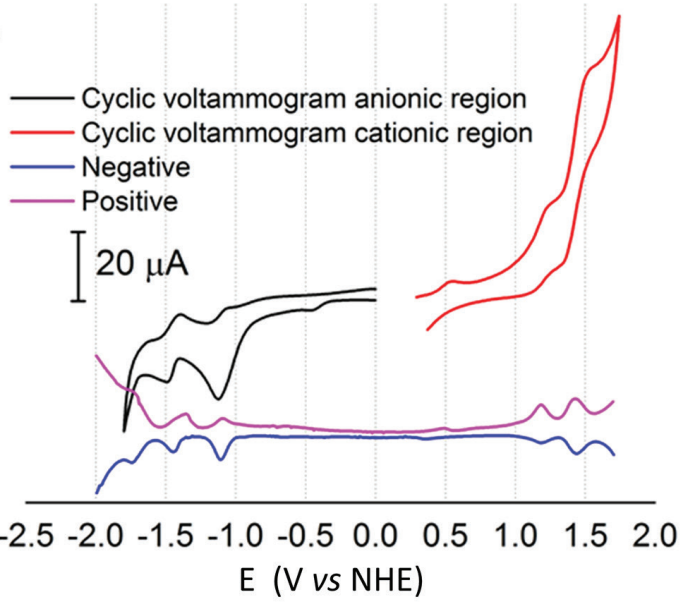

(b)

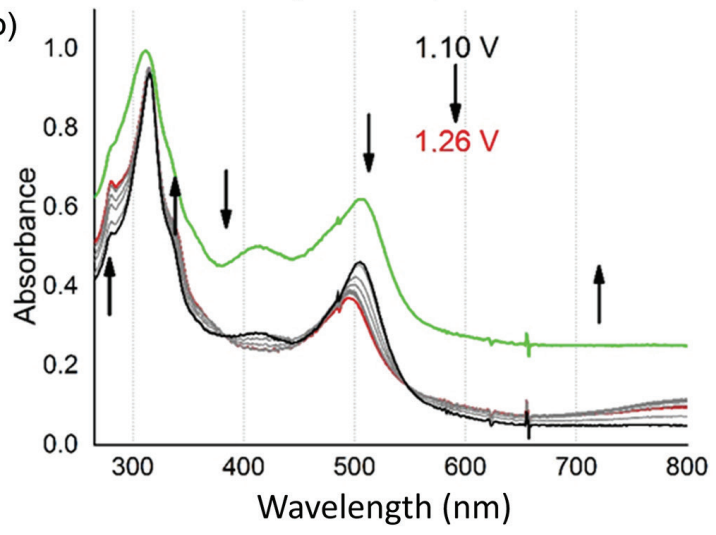

(c)

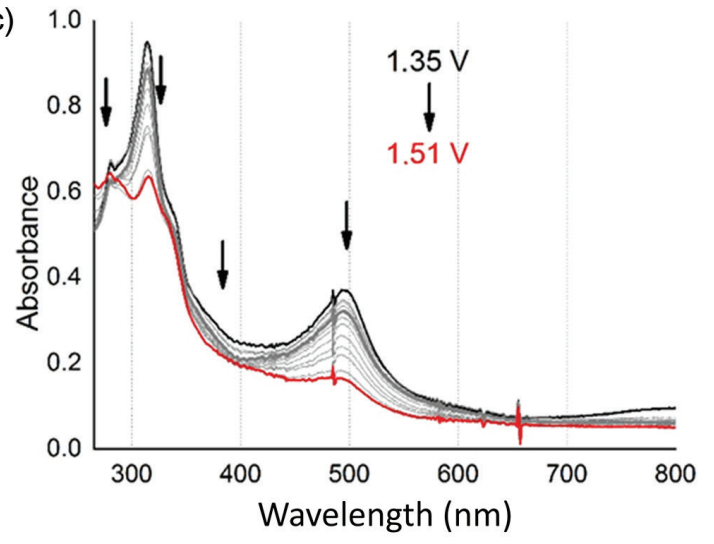

Figure 5. (a) Cyclic voltammogram of $1.0 \mathrm{mM}$ [Ru(py)(dcbpy)(TPAtpy)] in $0.10 \mathrm{M} \mathrm{TBAClO}_{4}$ DMF solution as electrolyte, $v=100 \mathrm{mV} \mathrm{s}^{-1}$, (b) electronic spectrum of [Ru(py)(dcbpy)(TPAtpy)] (green line) and spectroelectrochemical behavior associated with the first and (c) second oxidation processes.

incident light per unit area $\left(100 \mathrm{~mW} \mathrm{~cm} \mathrm{c}^{-2}\right)$. The current measured in the DSSCs comes from the photoinjection of electrons from the dye excited state LUMO orbital to the $\mathrm{TiO}_{2}$ conduction band (CB). On the other hand, the DSSCs voltage is generated by the energy difference between the Fermi level of $\mathrm{TiO}_{2}$ and the redox potential of the $\mathrm{I}_{3}{ }^{-} / \mathrm{I}^{-}$ couple in the electrolyte solution. Both the current and the voltage can be influenced by charge-transfer processes in the DSSCs. 


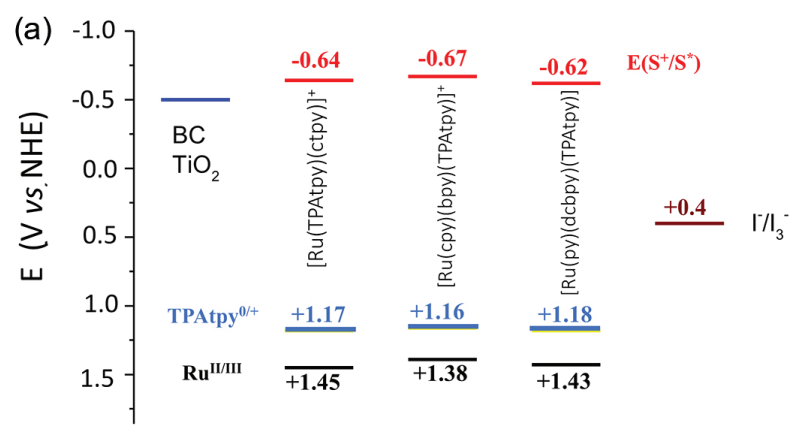

(b)

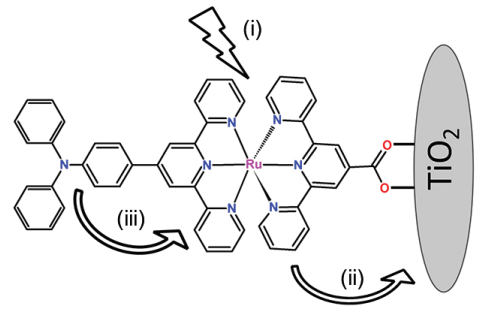

Figure 6. (a) Energy level diagram for DSSC employing pushpull ruthenium dye. (b) Electronic excitation (i), injection into the conduction band (ii) and electron transference from TPAtpy ligand (iii) on [Ru(TPAtpy)(ctpy)] dye on $\mathrm{TiO}_{2}$ surface. Similar events happen in $[\mathrm{Ru}(\mathrm{cpy})(\mathrm{bpy})(\mathrm{TPAtpy})]^{+}$and $[\mathrm{Ru}(\mathrm{py})(\mathrm{dcbpy})(\mathrm{TPAtpy})]$ dyes. E(S $\left.\mathrm{S}^{+} \mathrm{S}^{*}\right)$ is the redox potential of excited state of dyes.

Efficiency $=\frac{\mathrm{P}_{\max }}{\mathrm{P}_{\text {lamp }}}=\frac{\mathrm{J}_{\mathrm{sc}} \times \mathrm{V}_{\mathrm{oc}} \times \mathrm{FF}}{\mathrm{P}_{\text {Lamp }}}$

where FF is the fill factor.

The JV results showed higher $\mathrm{J}_{\mathrm{SC}}, \mathrm{V}_{\mathrm{OC}}$ and efficiency values (Table 2) for the $[\mathrm{Ru}(\mathrm{py})(\mathrm{dcbpy})$ (TPAtpy) $]$ push-pull dye and its current density $\left(2.34 \mathrm{~mA} \mathrm{~cm}{ }^{-2}\right)$ was up to 2.5 and 7.5 times greater respectively than that of [Ru(TPAtpy) (ctpy) $]\left(\mathrm{PF}_{6}\right)\left(0.91 \mathrm{~mA} \mathrm{~cm}^{-2}\right)$ and [Ru(cpy)(bpy)(TPAtpy)] $\left(\mathrm{PF}_{6}\right)(0.31 \mathrm{~mA} \mathrm{~cm}-2)$. Their $\mathrm{V}_{\mathrm{OC}}$ decreased in the order $[\mathrm{Ru}($ py) (dcbpy)(TPAtpy)] $(0.615 \mathrm{~V})>[\mathrm{Ru}($ cpy)(bpy) (TPAtpy) $]\left(\mathrm{PF}_{6}\right)(0.533 \mathrm{~V})>[\mathrm{Ru}(\mathrm{TPAtpy})(\mathrm{ctpy})]\left(\mathrm{PF}_{6}\right)$ $(0.501 \mathrm{~V})$, clearly indicating that the higher $\mathrm{J}_{\mathrm{SC}}$ and $\mathrm{V}_{\mathrm{OC}}$ values are responsible for the higher efficiency of the

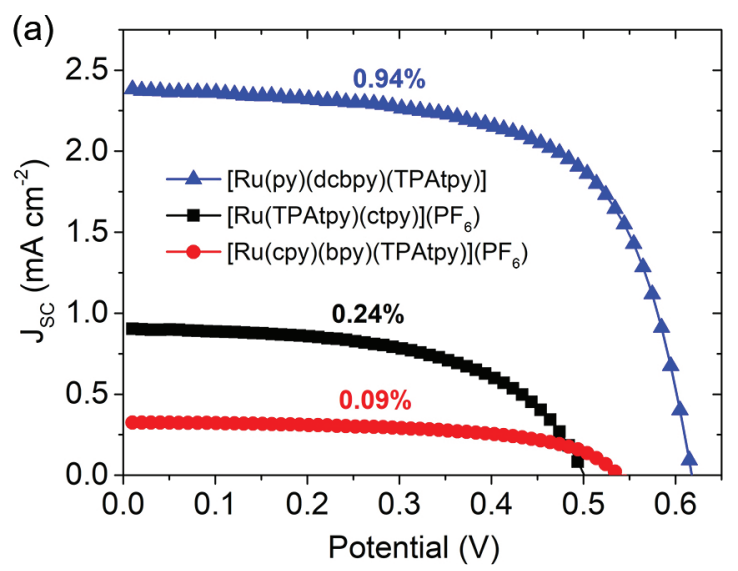

$[\operatorname{Ru}($ py)(dcbpy)(TPAtpy)] than the other two push-pull ruthenium dyes.

The photoaction spectra (IPCE) of the [Ru(TPAtpy) (ctpy) $]\left(\mathrm{PF}_{6}\right),[\mathrm{Ru}(\mathrm{cpy})($ bpy $)(\mathrm{TPAtpy})]\left(\mathrm{PF}_{6}\right)$ and $[\mathrm{Ru}($ py) (dcbpy)(TPAtpy)] dyes (Figure 7b) were measured in order to evaluate their efficiencies as a function of the wavelength of the incident radiation. The IPCE curves of the dyes presented similar profiles where the $495 \mathrm{~nm}$ MLCT transition plays a major role in the electron photoinjection to the $\mathrm{CB}$ of $\mathrm{TiO}_{2}$. The IPCE curve of pure $\mathrm{TiO}_{2}$ is presented in green shows increasing efficiencies at wavelengths shorter than $430 \mathrm{~nm}$ due to the intrinsic absorption of this semiconductor material. The conversion efficiency at $495 \mathrm{~nm}$ paralleled the respective $\mathrm{J}_{\mathrm{SC}}$ values, been higher for the $[\mathrm{Ru}(\mathrm{py})(\mathrm{dcbpy})(\mathrm{TPAtpy})](14.9 \%)$, followed by the $\left[\mathrm{Ru}\right.$ (TPAtpy)(ctpy)]( $\left.\mathrm{PF}_{6}\right)(5.7 \%)$ and the [Ru(cpy)(bpy)(TPAtpy)]( $\left.\mathrm{PF}_{6}\right)(1.0 \%)$ complex, indicating a strong correlation of the electron photoinjection from the sensitizers with the DSSCs short-circuit current values. Furthermore, the dicarboxy-bipyridine ligand present in the $[\mathrm{Ru}(\mathrm{py})(\mathrm{dcbpy})(\mathrm{TPAtpy})]$ dye was shown to be a better bridging ligand than the carboxy-terpyridine and carboxy-pyridine ligands respectively present in $[\mathrm{Ru}(\mathrm{TPAtpy})(\mathrm{ctpy})]^{2+}$ and $[\mathrm{Ru}(\mathrm{cpy})(\mathrm{bpy})(\mathrm{TPAtpy})]\left(\mathrm{PF}_{6}\right)_{2}$, promoting a more efficient electronic coupling with the mesoporous semiconductor. The higher electron injection efficiency through the dcbpy ligand is probably related to the presence of two carboxylate groups thus forming a more effective bond with the surface of the $\mathrm{TiO}_{2}$ and promoting a better coupling of the push-pull dye LUMO orbital with the conduction band of the semiconductor. Among the [Ru(TPAtpy)(ctpy)]( $\left.\mathrm{PF}_{6}\right)$ and [Ru(cpy)(bpy)(TPAtpy)] $\left(\mathrm{PF}_{6}\right)$ dyes, the first one has a higher efficiency at $495 \mathrm{~nm}$ probably due to the better acceptor properties of the ctpy ligand in relation to the cpy ligand, increasing the electron injection rate into the $\mathrm{CB}$ of the semiconductor. From the

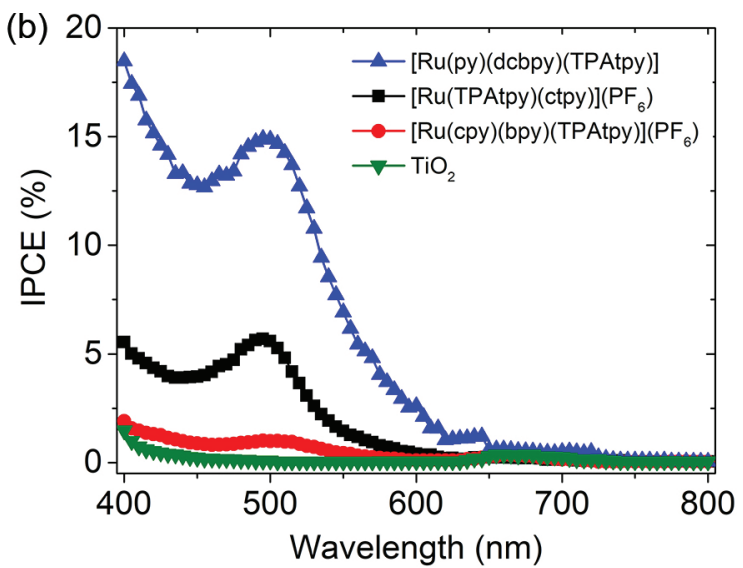

Figure 7. (a) JV curves with their respective overall photoconversion efficiencies, and (b) the IPCE curves DSSCs prepared with the [Ru(py)(dcbpy) (TPAtpy)], $[\mathrm{Ru}(\mathrm{TPAtpy})(\mathrm{ctpy})]\left(\mathrm{PF}_{6}\right)$ and $[\mathrm{Ru}(\mathrm{cpy})(\mathrm{bpy})(\mathrm{TPAtpy})]\left(\mathrm{PF}_{6}\right)$ push-pull ruthenium dyes. 
Table 2. Short circuit current $\left(\mathrm{J}_{\mathrm{SC}}\right)$, open circuit voltage $\left(\mathrm{V}_{\mathrm{OC}}\right)$, fill factor $(\mathrm{FF})$ and overall photoconversion efficiency of DSSCs prepared with the [Ru(TPAtpy) (ctpy) $]\left(\mathrm{PF}_{6}\right),[\mathrm{Ru}(\mathrm{cpy})(\mathrm{bpy})(\mathrm{TPAtpy})]\left(\mathrm{PF}_{6}\right),[\mathrm{Ru}(\mathrm{py})(\mathrm{dcbpy})(\mathrm{TPAtpy})]$ and $\mathrm{N} 719$ ruthenium dyes and the number of dyes per volume of mesoporous $\mathrm{TiO}_{2}$ film $(\Gamma)$

\begin{tabular}{lccccc}
\hline Ruthenium dye & $\mathrm{J}_{\mathrm{SC}} /\left(\mathrm{mA} \mathrm{cm}^{-2}\right)$ & $\mathrm{V}_{\mathrm{OC}} / \mathrm{V}$ & $\mathrm{FF} / \%$ & Efficiency $/ \%$ & $\Gamma /\left(\mathrm{mmols} \mathrm{cm}^{-3}\right)$ \\
\hline$[\mathrm{Ru}(\mathrm{TPAtpy})(\mathrm{ctpy})]\left(\mathrm{PF}_{6}\right)$ & $0.91 \pm 0.08$ & $0.497 \pm 0.006$ & $53.7 \pm 2.2$ & $0.24 \pm 0.03$ & $0.102 \pm 0.014$ \\
{$[\mathrm{Ru}(\mathrm{cpy})(\mathrm{bpy})(\mathrm{TPAtpy})]\left(\mathrm{PF}_{6}\right)$} & $0.31 \pm 0.12$ & $0.531 \pm 0.015$ & $57.1 \pm 1.6$ & $0.09 \pm 0.03$ & $0.030 \pm 0.002$ \\
{$[\mathrm{Ru}($ py)(dcbpy)(TPAtpy) } & $2.34 \pm 0.38$ & $0.612 \pm 0.006$ & $66.0 \pm 1.4$ & $0.94 \pm 0.14$ & $0.163 \pm 0.021$ \\
$\mathrm{~N} 719$ & $11.60 \pm 0.32$ & $0.711 \pm 0.006$ & $61.9 \pm 0.9$ & $5.10 \pm 0.08$ & $0.14^{\mathrm{a}}$ \\
\hline
\end{tabular}

'Value from reference 37. TPAtpy: 4-tripheylamine-2,2',2"-terpyridine; ctpy: 4-carboxy-2,2',2"-terpyridine; py: pyridine, dcbpy: 4,4'-dicarboxi-2,2'bipyridine, cpy: 4-carboxypyridine; bpy: 2,2'-bipyridine.

comparison between the $[\mathrm{Ru}(\mathrm{py})(\mathrm{dcbpy})(\mathrm{TPAtpy})]$ and N719 dyes, it was possible to verify a lower IPCE of the first ones due to the energetic position of its LUMO orbital $(-0.62 \mathrm{~V})$ being closer to the $\mathrm{TiO}_{2} \mathrm{BC}$ than the N719 LUMO orbital (Figure 6a) located at $-0.7 \mathrm{~V},{ }^{38}$ explaining the lower $\mathrm{J}_{\mathrm{SC}}$ and efficiency due to lower electron injection efficiency (Table 2).

Electrochemical impedance spectroscopy was used to evaluate the charge transfer and charge diffusion, as well as the electron recombination processes in the $\mathrm{TiO}_{2}$ material. Using this technique, the impedance at the $\mathrm{TiO}_{2} / \mathrm{TiO}_{2}, \mathrm{TiO}_{2} /$ electrolyte, $\mathrm{TiO}_{2} /$ dye and counter electrode/electrolyte interfaces of the DSSCs ${ }^{39,40}$ were quantitatively determined. In fact, three processes could be observed in the Nyquist (Figure 8a) and Bode Phase (Figure 8b) graphs, that were attributed, respectively, to the electron transfer from the counter electrode to the electrolyte at high frequencies, to the recombination of electron in $\mathrm{TiO}_{2} \mathrm{CB}$ with the redox electrolyte and the oxidized dye at intermediate frequencies, and the diffusion of ions present in the redox electrolyte at low frequencies.

Among the several impedance parameters, the one that was significantly modified in the push-pull dye series was the electron-transfer at the $\mathrm{TiO}_{2} /$ electrolyte and $\mathrm{TiO}_{2} /$ dye

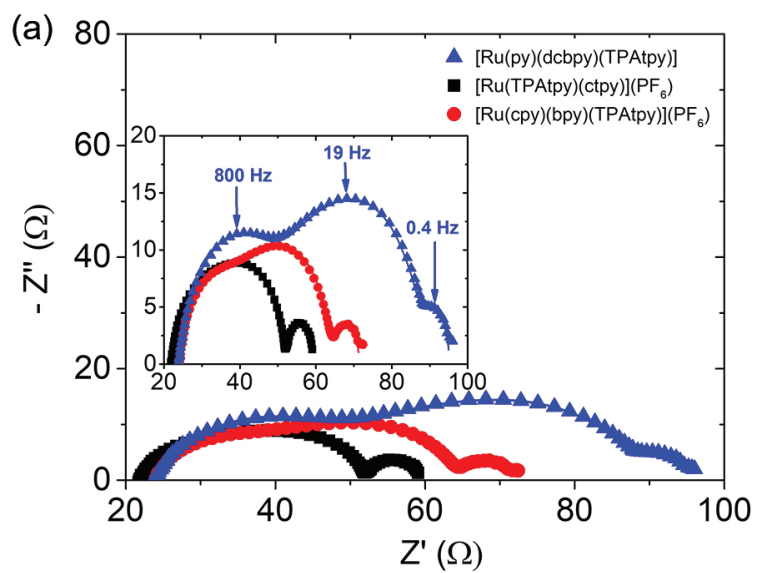

interfaces, changing the radius of the central semicircle in the Nyquist graph (Figure 8a) and shifting the corresponding band in the Bode Phase graph (Figure 8b) at intermediate frequencies. Thus, the electron recombination resistance decreased in the order [Ru(py)(dcbpy)(TPAtpy)] > $\left[\mathrm{Ru}(\text { cpy)(bpy)(TPAtpy) }]^{+}>\left[\mathrm{Ru}(\text { TPAtpy)(ctpy) }]^{+}\right.\right.$reflecting as the reduction of the diameter of the central semicircle (Figure $8 \mathrm{a}$ ). This tendency was accompanied by the displacement of the bands in the $10-1000 \mathrm{~Hz}$ range to higher frequencies (Figure $8 \mathrm{~b}$ ). The modifications observed in the Nyquist and Bode Phase plots indicate a decrease of the electron recombination in the sequence $\left[\mathrm{Ru}(\text { TPAtpy)(ctpy) }]^{+}>\left[\mathrm{Ru}(\text { cpy)(bpy)(TPAtpy) }]^{+}>[\mathrm{Ru}(\right.\right.$ py) (dcbpy)(TPAtpy)].

The impedance spectra were simulated using a transmission line equivalent circuit (Figure 9) to determine the resistive and capacitive characteristics of the photovoltaic devices. Thus, the semiconductor parameters such as the electron recombination resistance $\left(\mathrm{R}_{\mathrm{r}}\right)$, the electron diffusion resistance $\left(\mathrm{R}_{\mathrm{t}}\right)$ and the chemical capacitance $\left(\mathrm{C}_{\mu}\right)$, as well as the resistance $\left(R_{p t}\right)$ and the capacitance $\left(C_{p t}\right)$ of the counter electrode, as well as the diffusion resistance $\left(R_{w}\right)$ of ions in the electrolyte, were determined quantitatively (Table 3).

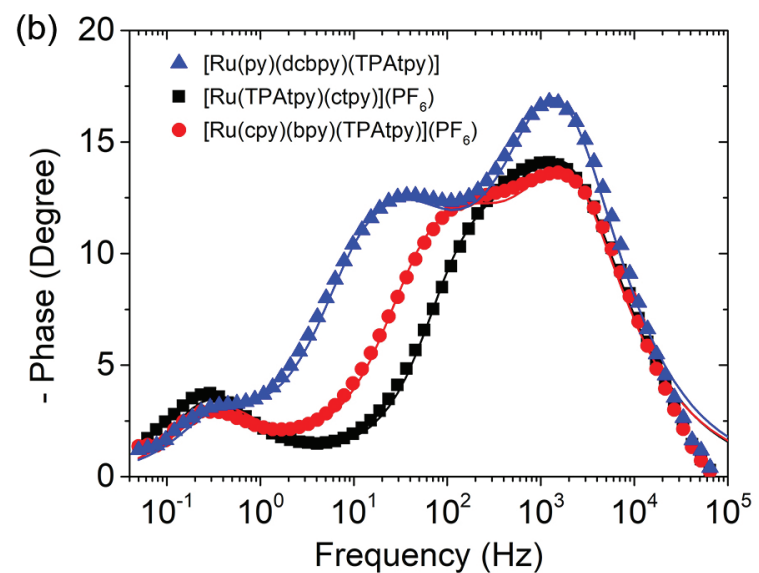

Figure 8. Nyquist (a) and Bode Phase (b) spectrum of DSSCs prepared with the [Ru(py)(dcbpy)(TPAtpy)], $[\operatorname{Ru}(\mathrm{TPAtpy})(\mathrm{ctpy})]\left(\mathrm{PF}_{6}\right)$ and $[\mathrm{Ru}(\mathrm{cpy})(\mathrm{bpy})$ (TPAtpy) $]\left(\mathrm{PF}_{6}\right)$ push-pull ruthenium dyes. 


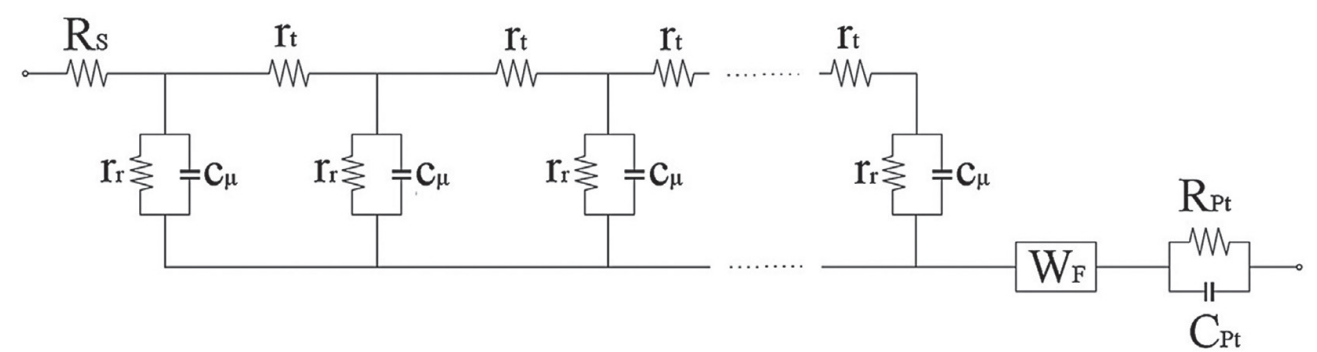

Figure 9. Transmission line equivalent circuit used to simulate the impedance spectra (reproduced from reference 39 with copyright permission 2016 from Elsevier).

Table 3. Serial resistance $\left(R_{s}\right)$ of the DSSCs, the electron diffusion resistance $\left(R_{t}\right)$, the electron recombination resistance $\left(R_{r}\right)$, the chemical capacitance $\left(C_{\mu}\right)$ of $\mathrm{TiO}_{2}$, the counter electrode resistance $\left(\mathrm{R}_{\mathrm{pt}}\right)$, the counter electrode capacitance $\left(\mathrm{C}_{\mathrm{pt}}\right)$ and the diffusion resistance $\left(\mathrm{R}_{\mathrm{w}}\right)$ of ions in the electrolyte determined by simulation of the impedance spectra using the transmission line equivalent circuit shown in Figure 9

\begin{tabular}{|c|c|c|c|c|c|c|c|}
\hline Ruthenium dye & $\mathrm{R}_{\mathrm{s}} / \Omega$ & $\mathrm{R}_{\mathrm{t}} / \Omega$ & $\mathrm{R}_{\mathrm{r}} / \Omega$ & $\mathrm{C}_{\mu} / \mu \mathrm{F}$ & $\mathrm{R}_{\mathrm{pt}} / \Omega$ & $\mathrm{C}_{\mathrm{pt}} / \mu \mathrm{F}$ & $\mathrm{R}_{\mathrm{w}} / \Omega$ \\
\hline$[\mathrm{Ru}(\mathrm{TPAtpy})(\mathrm{ctpy})]\left(\mathrm{PF}_{6}\right)$ & 21.7 & 43.9 & 7.7 & 203 & 10.5 & 10.0 & 8.0 \\
\hline$[\mathrm{Ru}(\mathrm{cpy})(\mathrm{bpy})(\mathrm{TPAtpy})]\left(\mathrm{PF}_{6}\right)$ & 23.6 & 57.6 & 13.5 & 259 & 10.3 & 9.6 & 8.6 \\
\hline$[\mathrm{Ru}(\mathrm{py})(\mathrm{dcbpy})(\mathrm{TPAtpy})]$ & 23.5 & 83.3 & 20.0 & 789 & 19.9 & 7.8 & 9.5 \\
\hline
\end{tabular}

TPAtpy: 4-tripheylamine-2,2',2"'-terpyridine; ctpy: 4-carboxy-2,2',2"-terpyridine; py: pyridine, dcbpy: 4,4'-dicarboxi-2,2'-bipyridine, cpy: 4-carboxypyridine; bpy: 2,2'-bipyridine.

A significant change of the $\mathrm{R}_{\mathrm{t}}, \mathrm{R}_{\mathrm{r}}$ and $\mathrm{C}_{\mu}$ parameters (Table 3) was observed, where the electron diffusion resistance has low influence on the $\mathrm{I} \times \mathrm{V}$ curve profiles of the DSSCs since the increase of $R_{t}$ in the $\left[\operatorname{Ru}(\text { TPAtpy)(ctpy) }]^{+}(43.9 \Omega),\left[\operatorname{Ru}(\text { cpy)(bpy)(TPAtpy) }]^{+}\right.\right.$ $(57.6 \Omega)$ and $[\operatorname{Ru}($ py)(dcbpy)(TPAtpy)] (83.3 $\Omega$ ) did not lead to a possible decrease in $\mathrm{J}_{\mathrm{SC}}$ in the same sequence. On the other hand, the $\mathrm{R}_{\mathrm{r}}$ and $\mathrm{C}_{\mu}$ parameters, directly related to the electron recombination processes, showed high influence on open circuit voltage since the increase of these parameters was accompanied by an increase of $\mathrm{V}_{\mathrm{OC}}$ (Table 2), as expected for the reduction of the rate of electron recombination process. In order to complement the impedance analysis, the lifetime $\left(t_{n}\right)$, the diffusion coefficient $\left(\mathrm{D}_{\mathrm{n}}\right)$ and the diffusion length $\left(\mathrm{L}_{\mathrm{n}}\right)$ of the electrons in $\mathrm{TiO}_{2}$ (Table 4) were calculated using the equations 2-4 below. As expected, there was a decrease of $D_{n}$ and an increase of $t_{n}$ in the sequence [Ru(TPAtpy)(ctpy) $]^{+},[R u(c p y)(b p y)(T P A t p y)]^{+}$and [Ru(py)(dcbpy)(TPAtpy)] due to the increase of $R_{t}, R_{r}$ and $\mathrm{C}_{\mu}$ parameters (Table 3). The [Ru(py)(dcbpy)(TPAtpy)] presented higher $t_{n}$ confirming the lower rate of electron recombination in the respective solar cells, that resulted in the highest $\mathrm{V}_{\mathrm{OC}}$. The diffusion lengths of all push-pull ruthenium dyes presented similar values around $7 \mu \mathrm{m}$, which is shorter than the $\mathrm{TiO}_{2}$ film thickness used in the DSSCs (ca. $14.5 \mu \mathrm{m}$ ), indicating that the overall efficiency was negatively affected by the high rates of electron recombination at the $\mathrm{TiO}_{2} /$ dye interface.

$$
\begin{aligned}
& \mathrm{t}_{\mathrm{n}}=\mathrm{R}_{\mathrm{r}} \times \mathrm{C}_{\mu} \\
& \mathrm{D}_{\mathrm{n}}=\frac{\mathrm{L}^{2}}{\mathrm{R}_{\mathrm{t}} \times \mathrm{C}_{\mu}} \\
& \mathrm{L}_{\mathrm{n}}=\sqrt{\mathrm{t}_{\mathrm{n}} \times \mathrm{D}_{\mathrm{n}}}
\end{aligned}
$$

where $\mathrm{L}$ is the thickness of mesoporous $\mathrm{TiO}_{2}$ film.

A possible explanation for the difference of the electron recombination rate of the push-pull ruthenium dyes can be attributed to the net charge on their structures. When comparing the structures of the complexes (Scheme 1) with deprotonated carboxylate group we can see that the $[\mathrm{Ru}(\mathrm{py})$ (dcbpy)(TPAtpy)] has zero charge and the [Ru(TPAtpy) (ctpy) $]^{1+}$ and the $\left[\mathrm{Ru}(\text { cpy)(bpy)(TPAtpy) }]^{1+}\right.$ have +1 charge.

Table 4. The lifetime $\left(t_{n}\right)$, diffusion coefficient $\left(\mathrm{D}_{\mathrm{n}}\right)$ and diffusion length $\left(\mathrm{L}_{\mathrm{n}}\right)$ of electrons in the $\mathrm{TiO}_{2}$ conduction band in the DSSCs

\begin{tabular}{lccc}
\hline Ruthenium dye & $\mathrm{t}_{\mathrm{n}} / \mathrm{ms}$ & $\mathrm{D}_{\mathrm{n}} /\left(10^{-4} \mathrm{~cm}^{2} \mathrm{~s}^{-1}\right)$ & $\mathrm{L}_{\mathrm{n}} / \mu \mathrm{m}$ \\
\hline$[\mathrm{Ru}(\mathrm{TPAtpy})(\mathrm{ctpy})]\left(\mathrm{PF}_{6}\right)$ & 1.6 & 2.60 & 6.4 \\
{$[\mathrm{Ru}(\mathrm{cpy})(\mathrm{bpy})(\mathrm{TPAtpy})]\left(\mathrm{PF}_{6}\right)$} & 3.5 & 1.36 & 6.9 \\
{$[\mathrm{Ru}($ py)$)($ dcbpy)(TPAtpy) $]$} & 15.8 & 0.29 & 6.8 \\
\hline
\end{tabular}

TPAtpy: 4-tripheylamine-2,2',2"'-terpyridine; ctpy: 4-carboxy-2,2',2'-terpyridine; py: pyridine, dcbpy: 4,4'-dicarboxi-2,2'-bipyridine, cpy: 4-carboxypyridine; bpy: 2,2'-bipyridine. 
According to a previous work, ${ }^{18}$ the increase of the negative charge in the $\left[\mathrm{Ru}(\mathrm{dcbpy})_{2}(\mathrm{btzH})_{2}\right]^{2-},\left[\mathrm{Ru}(\mathrm{dcbpy})_{2}(\mathrm{btzH})\right.$ (btz) $]^{3-}$ and $\left[\mathrm{Ru}(\mathrm{dcbpy})_{2}(\mathrm{btz})_{2}\right]^{4-}$ series (where dcbpy is the deprotonated 2,2'-bipyridyl-4,4'-dicarboxylic acid and btzH is the benzotriazole ligand) led to a decrease of the electron recombination process at the $\mathrm{TiO}_{2} /$ dye interface. This effect was attributed to a much larger average distance separating the $\mathrm{TiO}_{2}$ surface and the $\mathrm{I}_{3}^{-}$ions minimizing the back electron-transfer reaction. Similarly, the high recombination rates of the $[\mathrm{Ru}(\mathrm{TPAtpy})(\mathrm{ctpy})]^{1+}$ and the $\left[\mathrm{Ru}(\mathrm{cpy})(\mathrm{bpy})(\text { TPAtpy) }]^{1+}\right.$ can be attributed to the positive charge on these dyes that favor the approach of $\mathrm{I}_{3}{ }^{-}$ions to the $\mathrm{TiO}_{2}$ surface thus increasing the rate of the back-reaction process. The amount of push-pull ruthenium dye adsorbed on the surface of the $\mathrm{TiO}_{2}$ electrode was determined spectrophotometrically after desorbing the dyes from the nanocrystalline $\mathrm{TiO}_{2}$ films with a drop of $\mathrm{NaOH}$ solution ( $\mathrm{pH} 12$ ) and diluting to $5 \mathrm{~mL}$ with a $\mathrm{H}_{2} \mathrm{O}$ to evaluate quantitatively this effect (Table 2). The higher electron recombination rates of $[\mathrm{Ru} \text { (TPAtpy)(ctpy) }]^{1+}$ than $[\mathrm{Ru}(\mathrm{cpy})$ (bpy)(TPAtpy) $]^{1+}$ was attributed to its higher surface concentration and consequent positive charge on the $\mathrm{TiO}_{2}$ surface. In addition, the [Ru(py)(dcbpy)(TPAtpy)] showed lower rate of electron recombination even considering its higher concentration than $[\mathrm{Ru}(\mathrm{cpy})(\mathrm{bpy}) \text { (TPAtpy) }]^{1+}$. In this case, the zero charge of the [Ru(py)(dcbpy)(TPAtpy)] dye was determinant for this effect where the coordinated complexes tend to inhibit the approach of the redox electrolyte to the $\mathrm{TiO}_{2}$ surface.

In short, the surface concentration of the new series of push-pull ruthenium dyes on the $\mathrm{TiO}_{2}$ surface probably was determined by adsorption conformation and the number the carboxylate groups, where linear structures with larger number of anchoring groups are favored (Scheme 1). On the other hand, the adsorption of larger amounts of ruthenium dye with residual net positive charge tends to favor the back electron-transfer reaction process in detriment of the electron injection, thus decreasing the overall photoconversion efficiency of the DSSCs.

\section{Conclusions}

A new series of tris-(bipyridyl)ruthenium like complexes based on the TPA push-pull ligand were prepared by incorporation of cpy, dcbpy and ctpy ligands, and characterized by electrochemical and spectroscopic techniques. Those ruthenium dyes were designed to allow distinct adsorption conformations and orientations of the TPA donor-group on the semiconductor surface and study the effects on the photoconversion efficiency of dye sensitized solar cells. In fact, the electron injection and electron recombination properties of the $\mathrm{TiO}_{2}$ electrode sensitized with the push-pull ruthenium dyes were significantly altered by their structural and adsorption conformation properties, that influenced their surface concentration and defined the residual charge on the $\mathrm{TiO}_{2}$ surface. The adsorption in more upright position by a larger number of anchoring groups enhanced the electron injection into $\mathrm{TiO}_{2} \mathrm{CB}$ improving the $\mathrm{J}_{\mathrm{sc}}, \mathrm{V}_{\mathrm{OC}}$ and overall efficiency parameters. However, if the dye has a positive overall charge it may increase the back electron-transfer reactions and induce a decrease in both $\mathrm{V}_{\mathrm{oc}}$ and efficiency. In short, the surface concentration and net charge of the dyes on $\mathrm{TiO}_{2}$, leading to a 10 times larger photoconversion efficiency for $[\mathrm{Ru}(\mathrm{py})(\mathrm{dcbpy})(\mathrm{TPAtpy})]$ than $[\mathrm{Ru}(\mathrm{cpy})$ (bpy)(TPAtpy)] $\left(\mathrm{PF}_{6}\right)$, demonstrating that 2,2'-bipyridine4,4'-dicarboxylic acid is a much better anchoring ligand.

\section{Supplementary Information}

Supplementary data are available free of charge at http://jbcs.sbq.org.br as PDF file.

\section{Acknowledgments}

The authors are grateful to Conselho Nacional de Desenvolvimento Científico e Tecnológico (CNPq), Coordenação de Aperfeiçoamento de Pessoal de Nível Superior (CAPES), and Fundação de Amparo à Pesquisa do Estado de São Paulo (FAPESP). WAAR acknowledges CNPq for the scholarship (160972/2015-9); and KA acknowledge FAPESP (2018/21489-1) and CNPq (401581/2016-0 and 303137/2016-9) for the financial support.

\section{References}

1. Huang, W.-K.; Wu, H.-P.; Lin, P.-L.; Diau, E. W.-G.; J. Phys. Chem. C 2013, 117, 2059.

2. Singh, S. P.; Gupta, K. S. V.; Chandrasekharam, M.; Islam, A.; Han, L.; Yoshikawa, S.; Haga, M.-A.; Roy, M. S.; Sharma, G. D.; ACS Appl. Mater. Interfaces 2013, 5, 11623.

3. O’ Regan, B.; Gratzel, M.; Nature 1991, 353, 737.

4. Kono, T.; Masaki, N.; Nishikawa, M.; Tamura, R.; Matsuzaki, H.; Kimura, M.; Mori, S.; ACS Appl. Mater. Interfaces 2016, 8,16677 .

5. Sinn, S.; Schulze, B.; Friebe, C.; Brown, D. G.; Jäger, M.; Altuntaş, E.; Kübel, J.; Guntner, O.; Berlinguette, C. P.; Dietzek, B.; Schubert, U. S.; Inorg. Chem. 2014, 53, 2083.

6. Araki, K.; Losco, P.; Engelmann, F. M.; Winnischofer, H.; Toma, H. E.; J. Photochem. Photobiol., A 2001, 142, 25.

7. Barpuzary, D.; Banik, A.; Panda, A. N.; Qureshi, M.; Inorg. Chem. 2014, 53, 5417. 
8. Fan, S.-Q.; Kim, C.; Fang, B.; Liao, K.-X.; Yang, G.-J.; Li, C.-J.; Kim, J.-J.; Ko, J.; J. Phys. Chem. C 2011, 115, 7747.

9. Nazeeruddin, M. K.; Klein, C.; Liska, P.; Grätzel, M.; Coord. Chem. Rev. 2005, 249, 1460.

10. Hagfeldt, A.; Grätzel; M.; Acc. Chem. Res. 2000, 33, 269.

11. Wadman, S. H.; van Leeuwen, Y. M.; Havenith, R. W. A.; van Klink, G. P. M.; van Koten, G.; Organometallics 2010, 29, 5635.

12. Pashaei, B.; Shahroosvand, H.; Graetzel, M.; Nazeeruddin, M. K.; Chem. Rev. 2016, 116, 9485.

13. Cheng, Y.; Yang, G.; Jiang, H.; Zhao, S.; Liu, Q.; Xie, Y.; ACS Appl. Mater. Interfaces 2018, 10, 38880.

14. Lu, Y.; Song, H.; Li, X.; Ågren, H.; Liu, Q.; Zhang, J.; Zhang, X.; Xie, Y.; ACS Appl. Mater. Interfaces 2019, 11, 5046.

15. Zeng, K.; Lu, Y.; Tang, W.; Zhao, S.; Liu, Q.; Zhu, W.; Tiana, H.; Xie, Y.; Chem. Sci 2019, 10, 2186.

16. Zeng, K.; Tang, W.; Li, C.; Chen, Y.; Zhao, S.; Liu, Q.; Xie, Y.; J. Mater. Chem. A 2019, 7, 20854.

17. Kurumisawa, Y.; Higashino, T.; Nimura, S.; Tsuji, Y.; Iiyama, H.; Imahori; J. Am. Chem. Soc. 2019, 141, 9910.

18. Tang, J.; Wu, W.; Hua, J.; Li, J.; Lia, X.; Tian, H.; Energy Environ. Sci. 2009, 2, 982.

19. Wan, Z.; Jia, C.; Duan, Y.; Zhou, L.; Zhang, J.; Lin, Y.; Shia, Y.; RSC Adv. 2012, 2, 4507.

20. Guimaraes, R. R.; Parussulo, A. L. A.; Toma, H. E.; Araki, K.; Inorg. Chim. Acta 2013, 404, 23.

21. Parussulo, A. L. A.; Matias, T. A.; Guimaraes, R. R.; Toma, S. H.; Araki, K.; Toma, H. E.; Inorg. Chim. Acta 2016, 453, 764.

22. Guimaraes, R. R.; Parussulo, A. L. A.; Matias, T. A.; Guimaraes, R. R.; Araki, K.; Toma, H.; Electrochim. Acta 2017, 255, 92.

23. Parussulo, A. L. A.; Iglesias, B. A.; Toma, H. E.; Araki, K.; Chem. Commun. 2012, 48, 6939.

24. Mondal, P. C.; Manna, A. K.; New J. Chem. 2016, 40, 5775.

25. Zhao, L.; Wagner, P.; van der Salm, H.; Clarke, T. M.; Gordon, K. C.; Mori, S.; Mozer, A. J.; J. Phys. Chem. C 2015, 119, 5350.

26. Imahori, H.; Umeyama, T.; Kurotobia, K.; Takanoa, Y.; Chem. Commun. 2012, 48, 4032.
27. Imahori, H.; Hayashi, S.; Hayashi, H.; Oguro, A.; Eu, S.; Umeyama, T.; Matano, Y.; J. Phys. Chem. C 2009, 113, 18406.

28. Benavides, P. A.; Matias, T. A.; Araki, K.; Dalton Trans. 2017, 46, 15567.

29. Matias, T. A.; Mangoni, A. P.; Toma, S. H.; Rein, F. N.; Rocha, R. C.; Toma, H. E.; Araki, K.; Eur. J. Inorg. Chem. 2016, 36, 5547.

30. Matias, T. A.; Parussulo, A. L. A.; Benavides, P. A.; Guimaraes, R. R.; Dourado, A. H. B.; Nakamura, M.; Torresi, S. I. C.; Bertotti, M.; Araki, K.; Electrochim. Acta 2018, 283, 18.

31. Metcalfe, C.; Spey, S.; Adams, H.; Thomas, J. A.; J. Chem. Soc., Dalton Trans. 2002, 24, 4732.

32. Wang, Q.; Campbell, W. M.; Bonfantani, E. E.; Jolley, K. W.; Officer, D. L.; Walsh, P. J.; Gordon, K.; Humphry-Baker, R.; Nazeeruddin, M. K.; Grätzel, M.; J. Phys. Chem. B 2005, 109, 15397.

33. Jakubikova, E.; Chen, W.; Dattelbaum, D. M.; Rein, F. N.; Rocha, R. C.; Martin, R. L.; Batista, E. R.; Inorg. Chem. 2009, 48, 10720.

34. Matias, T. A.; Rein, F. N.; Rocha, R. C.; Formiga, A. L. B.; Toma, H. E.; Araki, K.; Dalton Trans. 2019, 48, 3009.

35. Campbell, W. M.; Jolley, K. W.; Wagner, P.; Wagner, K.; Walsh, P. J.; Gordon, K. C.; Schmidt-Mende, L.; Nazeeruddin, M. K.; Wang, Q.; Grätzel, M.; Officer, D. L.; J. Phys. Chem. C 2007, 111,11760 .

36. Ning, Z.; Fu, Y.; Tian, H.; Energy Environ. Sci. 2010, 3, 1170.

37. Guimaraes, R. R.; Parussulo, A. L. A.; Araki, K.; Electrochim. Acta 2016, 222, 1378.

38. Hagfeldt, A.; Boschloo, G.; Sun, L.; Kloo, L.; Pettersson, H.; Chem. Rev. 2010, 110, 6595.

39. Guimarães, R. R.; Parussulo, A. L. A.; Toma, H. E.; Araki, K.; Electrochim. Acta 2016, 188, 523.

40. Wang, Q.; Moser, J.-E.; Gratzel, M.; J. Phys. Chem. B 2005, 109, 14945.
Submitted: January 12, 2020

Published online: April 27, 2020 